\title{
A Novel ALDH2 Activator AD-9308 Improves Diastolic and Systolic Myocardial Functions in Streptozotocin-Induced Diabetic Mice
}

\author{
Hsiao-Lin Lee ${ }^{1,+}$, Siow-Wey Hee ${ }^{1,+}$, Chin-Feng Hsuan ${ }^{2,3,4,+}$, Wenjin Yang ${ }^{5}$, Jing-Yong Huang ${ }^{1}$, Ya-Ling Lin ${ }^{1}$, \\ Chih-Neng Hsu ${ }^{6}$, Juey-Jen Hwang ${ }^{1,6}$, Shiau-Mei Chen ${ }^{1}$, Zhi-Zhong Ding ${ }^{7}$, Tung-Yuan Lee ${ }^{7}$, Yu-Chiao Lin ${ }^{8}$, \\ Feng-Chiao Tsai ${ }^{1,8}{ }^{1}$, , Wei-Lun Su ${ }^{1}$, Li-Yun Chueh ${ }^{8}$, Meng-Lun Hsieh ${ }^{1,8}$, Che-Hong Chen ${ }^{9}$, \\ Daria Mochly-Rosen ${ }^{9}$, Yi-Cheng Chang ${ }^{1,7,10, *}$ and Lee-Ming Chuang 1,11,12,*
}

1 Department of Internal Medicine, National Taiwan University Hospital, Taipei 100225, Taiwan; leehsiaolin@ntu.edu.tw (H.-L.L.); d91448003@ntu.edu.tw (S.-W.H.); jingyonghuang@ntu.edu.tw (J.-Y.H.); s920449@yahoo.com.tw (Y.-L.L.); jueyhwang@ntu.edu.tw (J.-J.H.); smcs7133@ntu.edu.tw (S.-M.C.); tsaifc@ntu.edu.tw (F.-C.T.); weilunsu0310@ntu.edu.tw (W.-L.S.); r04455002@ntu.edu.tw (M.-L.H.)

2 Division of Cardiology, Department of Internal Medicine, E-Da Hospital, Kaohsiung 824410, Taiwan; calvin34@isu.edu.tw

3 Division of Cardiology, Department of Internal Medicine, E-Da Dachang Hospital, Kaohsiung 82445, Taiwan

4 School of Medicine, College of Medicine, I-Shou University, Kaohsiung 840203, Taiwan

5 Foresee Pharmaceuticals, Co., Ltd., Taipei 11560, Taiwan; wenjin.yang@foreseepharma.com

6 Department of Internal Medicine, National Taiwan University Hospital, Yunlin Branch, Yunlin 64041, Taiwan; Y00677@ms1.ylh.gov.tw

updates

Citation: Lee, H.-L.; Hee, S.-W.; Hsuan, C.-F.; Yang, W.; Huang, J.-Y.; Lin, Y.-L.; Hsu, C.-N.; Hwang, J.-J.; Chen, S.-M.; Ding, Z.-Z.; et al. A Novel ALDH2 Activator AD-9308 Improves Diastolic and Systolic Myocardial Functions in Streptozotocin-Induced Diabetic Mice. Antioxidants 2021, 10, 450. https:// doi.org/10.3390/antiox10030450

Academic Editor: Fabrizio Gentile

Received: 31 January 2021

Accepted: 11 March 2021

Published: 13 March 2021

Publisher's Note: MDPI stays neutral with regard to jurisdictional claims in published maps and institutional affiliations.

Copyright: (c) 2021 by the authors. Licensee MDPI, Basel, Switzerland. This article is an open access article distributed under the terms and conditions of the Creative Commons Attribution (CC BY) license (https:/ / creativecommons.org/licenses/by/ $4.0 /)$.
7 Graduate Institute of Medical Genomics and Proteomics, National Taiwan University, Taipei 10055, Taiwan; r07455006@ntu.edu.tw (Z.-Z.D.); r08455003@ntu.edu.tw (T.-Y.L.)

8 Department of Pharmacology, National Taiwan University, Taipei 100233, Taiwan; d05443004@ntu.edu.tw (Y.-C.L.); r09455005@ntu.edu.tw (L.-Y.C.)

9 Department of Chemical and Systems Biology, Stanford University School of Medicine, Stanford, CA 94305, USA; chehong@stanford.edu (C.-H.C.); mochly@stanford.edu (D.M.-R.)

10 Institute of Biomedical Sciences, Academia Sinica, Taipei 115024, Taiwan

11 Graduate Institute of Molecular Medicine, National Taiwan University, Taipei 100233, Taiwan

12 Graduate Institute of Clinical Medicine, National Taiwan University, Taipei 100233, Taiwan

* Correspondence: yichengchang@ntu.edu.tw (Y.-C.C.); leeming@ntu.edu.tw (L.-M.C.)

+ These three authors contribute equally to this work.

\begin{abstract}
Diabetes mellitus has reached epidemic proportion worldwide. One of the diabetic complications is cardiomyopathy, characterized by early left ventricular (LV) diastolic dysfunction, followed by development of systolic dysfunction and ventricular dilation at a late stage. The pathogenesis is multifactorial, and there is no effective treatment yet. In recent years, 4-hydroxy-2-nonenal (4-HNE), a toxic aldehyde generated from lipid peroxidation, is implicated in the pathogenesis of cardiovascular diseases. Its high bioreactivity toward proteins results in cellular damage. Mitochondrial aldehyde dehydrogenase $2(\mathrm{ALDH} 2)$ is the major enzyme that detoxifies 4-HNE. The development of small-molecule ALDH2 activator provides an opportunity for treating diabetic cardiomyopathy. This study found that AD-9308, a water-soluble andhighly selective ALDH2 activator, can improve LV diastolic and systolic functions, and wall remodeling in streptozotocin-induced diabetic mice. AD-9308 treatment dose-dependently lowered serum 4-HNE levels and 4-HNE protein adducts in cardiac tissue from diabetic mice, accompanied with ameliorated myocardial fibrosis, inflammation, and apoptosis. Improvements of mitochondrial functions, sarco/endoplasmic reticulumcalcium handling and autophagy regulation were also observed in diabetic mice with AD-9308 treatment. In conclusion, ADLH2 activation effectively ameliorated diabetic cardiomyopathy, which may be mediated through detoxification of 4-HNE. Our findings highlighted the therapeutic potential of ALDH2 activation for treating diabetic cardiomyopathy.
\end{abstract}

Keywords: diabetic cardiomyopathy; 4-hydroxy-2-nonenal; mitochondrial aldehyde dehydrogenase 2; AD-9308 


\section{Introduction}

Diabetes mellitus (DM) is one of the biggest and rapidly increasing health issues in the 21st century, resulting primarily from sedentary lifestyle and high-calorie diets. The worldwide diabetes population in 2019 was estimated to be 463 million and was expected to reach 578 million by 2030 and 700 million by 2045 [1]. The progression of diabetes is usually accompanied with complications, such as cardiovascular diseases, neuropathy, nephropathy, and retinopathy [2].

Relationship between DM and cardiovascular diseases is well established. DM is a major risk factor for atherosclerotic cardiovascular diseases. In addition, the incidence of heart failure in diabetic patient is also comparatively high [3,4]. Development and progression of heart failure in diabetic patients, without coronary artery, valvular heart disease, or hypertension, was first described in 1972 [5]. This form of heart failure was termed as "diabetic cardiomyopathy". Initially, diabetic cardiomyopathy is characterized by subclinical changes in structure and function, including myocardial fibrosis and stiffness, and impaired myocardial relaxation. With progression of diabetic cardiomyopathy, left ventricular (LV) remodeling and advanced diastolic dysfunction develop, and it evolves to systolic dysfunction eventually $[6,7]$.

The mechanism behind diabetic cardiomyopathy is complex and multifactorial. Previous studies reported that hyperglycemia (causing glucotoxicity) and elevated fatty acid levels (causing lipotoxicity) in diabetes caused formation of reactive oxygen species, increased inflammation andmyocardial fibrosis, impaired mitochondrial function, and deranged calcium homeostasis [7-12].In diabetic hearts, proinflammatory cytokines including interleukin $1 \beta$ (IL-1 $\beta$ ), IL-6, and tumor necrosis factor- $\alpha$ (TNF- $\alpha$ ) expression levels first increased [13-16], followed by activation of transforming growth factor $\beta$ (TGF- $\beta$ ) and connective tissue growth factor (CTGF) that inducesfibrosis in diabetic cardiomyopathy [8-17]. Moreover, mitochondrial damage and decreased sarco/endoplasmic reticulum (SR/ER) $\mathrm{Ca}^{2+}$ release were observed in diabetic hearts [18-21].

In DM, lipid peroxidation, induced by hyperglycemia-mediated oxidative stress, generates reactive aldehydes [22]. These aldehydes form covalent adducts with DNA and proteins in tissues, resulting in protein dysfunction, alteration of intracellular signaling, and organelle damage [22-24]. 4-hydroxy-2-nonenal (4-HNE) generated from lipid peroxidation when polyunsaturated fatty acids in bilayer cell membrane are attacked by reactive oxygen species, is one of most studied bioreactive aldehydes [22]. Both serum and tissue levels of 4-HNE were increased under diabetic condition, making it as a potential biomarker of diabetic complications [24-26]. Studies have shown the association of 4-HNE with heart diseases, such as atherosclerosis, myocardial ischemic injury, ventricular hypertrophy, and cardiomyopathy $[27,28]$. Animal studies also showed increased 4-HNE or 4-HNE protein adducts in myocardial tissues, causing cardiac damage in diabetic rats and mice $[6,27,29-31]$. Therefore, elevation of 4-HNE may contribute to structural and functional abnormalities in diabetic hearts.

HNE can be detoxified by adduction of the C-3 electrophilic center with reduced glutathione (GSH) by glutathione-S-transferases, oxidation of the aldehyde group by aldehyde dehydrogenases (ALDH) to form 4-hydroxy-2-nonenoic acid (HNEAcid), and reduction of the aldehyde group to an alcohol by aldo-keto-reductases or alcohol dehydrogenases to form 1,4-dihydroxynonene [32]. Aldehyde dehydrogenase 2 (ALDH2), located in mitochondria, is one of the major enzymes for detoxifying $4-\mathrm{HNE}$, which in turn protects the heart from oxidative stress damage $[28,33]$. The expression level and enzymatic activity of ALDH2 were reduced in diabetic hearts. Overexpression of ALDH2 was reported to prevent cardiac dysfunction in streptozotocin (STZ)-induced diabetic mice. In addition, a small-molecule ALDH2 activator, Alda-1, was shown to enhance ALDH2 activity and attenuate myocardial injury caused by ischemia-reperfusion [8,28]. The development of small-molecule ALDH2 activators promises a potential treatment for diabetic cardiomyopathy.

AD-9308 is a water-soluble and highly selective ALDH2 activator that is more potent than the prototype drug Alda-1 [34]. In this study, STZ-induced diabetic mice were 
treated with AD-9308 to examine whether activation of ALDH2 could reverse diabetic cardiomyopathy. Our findings showed that AD-9308 treatment amended both diastolic and systolic cardiac dysfunctions, and reversed ventricular wall remodeling through reducing myocardial fibrosis, inflammation, apoptosis, mitochondrial damage, and improving mitochondrial respiration and calcium homeostasis in diabetic mice.

\section{Materials and Methods}

\subsection{Animals}

Experiments were performed on C57BL6/J mice according to National Ethical guidelines and were approved by the Institutional Animal Care and Use Committee of the Medical College of National Taiwan University (Ethical approval number: IACUC 20200046), which is accredited by the Association for Assessment and Accreditation of Laboratory Animal Care International (AAALAC). Hyperglycemia was induced in 8-week-old mice by intraperitoneal (i.p.) injection of STZ (40 mg/kg/day) for one week. Mice were given 0 (water vehicle), 60, and $180 \mathrm{mg} / \mathrm{kg} /$ day of AD-9308 by daily oral gavage since the age of 10 weeks (Figure 1a). The chemical structure of AD-9308 was shown in previous literature [34]. No anti-diabetic therapy was used. The non-diabetic control mice were given vehicles (water) by daily oral gavage.
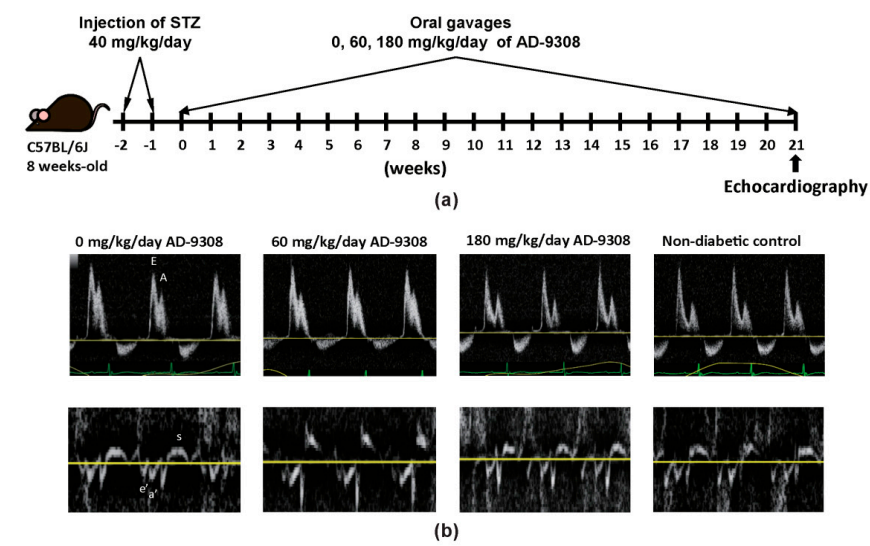

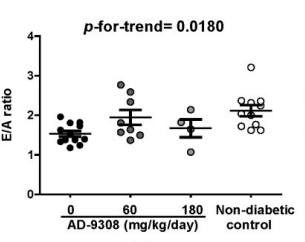

(C)

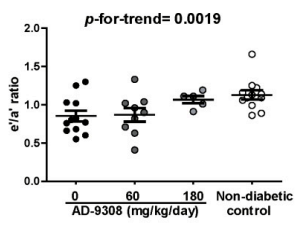

(f)

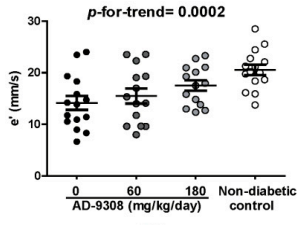

(d)

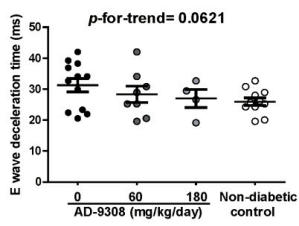

(g)

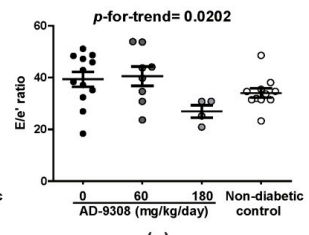

(e)

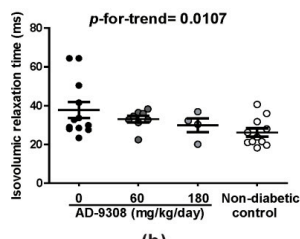

(h)

Figure 1. AD-9308 treatment ameliorated left ventricular diastolic dysfunction in streptozotocin (STZ)-induced diabetic mice. (a) flow chart illustrating the experimental design, (b) representative pulse wave and tissue Doppler echocardiograms. The (c) mean E/A ratio, (d) e' wave, (e) E/e' ratio, (f) $\mathrm{e}^{\prime} / \mathrm{a}^{\prime}$ ratio, (g) E wave deceleration time and (h) isovolumic relaxation time were measured in STZ-induced diabetic mice treated with $0,60,180 \mathrm{mg} / \mathrm{kg} /$ day of AD-9308 by oral gavages and non-diabetic control mice. Data are presented as mean \pm SEM ( $n=14-16$ per group). $p$-for-trend was used to test thelinear trend.

At the end of experiments, mice were sacrificed by $\mathrm{CO}_{2}$ euthanasia and then the heart was harvested. A portion of fresh heart tissue was fixed with $4 \%$ formaldehyde for 
histopathological study, and another small piece was soaked in REzolTM C\&T reagent (Protech Technology Enterprise Co., Ltd., Taipei, Taiwan) for gene expression assay. The remaining portion of heart was stored in liquid nitrogen for other assays.

\subsection{Echocardiography}

At 5 months post-STZ induction of diabetes, STZ-induced diabetic mice with or without AD-9308 treatment and non-diabetic control mice received echocardiographic examination. Echocardiography was performed using a high frequency ultrasound imaging system Prospect T1 (S-Sharp Corporation, Taipei, Taiwan) with a $40 \mathrm{MHz}$ transducer. Mice were anesthetized with isoflurane (3-4\% for induction and $1-2 \%$ for maintenance) during examination. Two-dimensional M-mode echocardiography was performed in the parasternal long-axis view for measuring the parameters of the LV geometry, including LV internal dimension at end diastole and systole (LVIDd and LVIDs), end-diastolic interventricular septal thickness (IVSd) and LV posterior wall thickness (LVPWd). LV endocardial fractional shortening was calculated as (LVIDd - LVIDs)/LVIDd $\times 100 \%$. LV end diastolic volume $(\mathrm{EDV})$ was calculated as [7.0/(2.4 + LVIDd) $] \times \mathrm{LVIDd}^{3}$ and $\mathrm{LV}$ end systolic volume $\left(\right.$ ESV) was calculated as $[7.0 /(2.4+\mathrm{LVIDs})] \times \mathrm{LVIDs}^{3}$. Stroke volume was then derived as $\mathrm{EDV}-\mathrm{ESV}$, and ejection fraction as $(\mathrm{EDV}-\mathrm{ESV}) / \mathrm{EDV} \times 100 \%$. LV mass was calculated as $1.05 \times\left[\left(\operatorname{IVSd}+\mathrm{LVIDd}+\mathrm{LVPWd}^{3}-\mathrm{LVIDd}^{3}\right]\right.$. Early diastolic mitral inflow velocity $(\mathrm{E})$, late diastolic mitral inflow velocity $(\mathrm{A})$, deceleration time of $\mathrm{E}$ wave, and isovolumic relaxation time were acquired from the apical 4-chamber view using pulsed-wave Doppler, and the E/A ratio was calculated. Myocardial velocities including peak systolic (s), early ( $\left.\mathrm{e}^{\prime}\right)$ and late $\left(a^{\prime}\right)$ diastolic mitral annular velocities were measured through the apical 4-chamber view using tissue Doppler, and the $\mathrm{e}^{\prime} / \mathrm{a}^{\prime}$ ratio was calculated. The E/e' ratio was applied to estimate the LV filling pressure. Each parameter was quantified with the average of measurements obtained from three consecutive cardiac cycles.However, E wave and A wave of some mice are missing in some mice due to technical difficulty.

\subsection{Hematoxylin and Eosin (HEE) Staining}

The mice heart from each group were soaked in $4 \%$ formalin, dehydrated through graded ethanol and embedded in paraffin wax. The paraffin-embedded tissue blocks were cut into $0.2 \mathrm{im}$-thick paraffin sections. The tissue sections were deparaffinized by immersing in xyleneand rehydrated. Sections were dyed with hematoxylin and eosin and then rinsed with water. Dried sections were mounted and were taken photomicrographs using Olympus BX51 microscope combined with Olympus DP72 camera and CellSens Standard 1.14 software (Olympus, Hamburg, Germany).

\subsection{Serum 4-HNE Level Measurement}

Blood was collected from mice fasted for $4 \mathrm{~h}$, and then was spun at $7000 \times g$ for $10 \mathrm{~min}$ to obtain serum. Serum 4-HNE levels were measured using ELISA kits (cat. No. EELM2677, Elabscience, Wuhan, China) and VICTOR Multilabel plate reader (PerkinElmer, West Berlin, NJ, USA).

\subsection{ImmunoblottingAnalysis}

Total proteins from cardiac tissues were separated using $10 \%$ or $15 \%$ SDS-PAGE and then transferred to the PVDF membrane. The primary antibodies used in this study are listed in Table S1. The signals developed with ECL reagent (Millipore, Burlington, MA, USA) were captured by MultiGel-21 (Top Bio, Taipei, Taiwan).

\subsection{ALDH2 Enzymatic Activity Assays}

ALDH2 activity was measured by monitoring the production rate of $\mathrm{NADH} / \mathrm{min}$ at $340 \mathrm{~nm}$ and $25^{\circ} \mathrm{C}$. Enzyme activity was assayed in $100 \mu \mathrm{L}$ of reaction mixtures containing $50 \mathrm{mM} \mathrm{Na}_{4} \mathrm{P}_{2} \mathrm{O}_{7}$ (pH 9.5), 0.01\% BSA, $2.5 \mathrm{mM} \mathrm{NAD}^{+}, 100 \mu \mathrm{M} 4-\mathrm{HNE}$, and protein lysate from heart tissue, and then was monitoredwith the change in absorbance at $340 \mathrm{~nm}$ for 
5 min by spectrophotometer (Infinite ${ }^{\circledR}$ M Plex, Tecan Trading AG, Zurich, Switzerland). Relative ALDH2 activity was compared to ALDH2 activity of non-diabetic control mice.

\subsection{Gene Expression Analysis}

RNA was extracted from frozen cardiac tissues using the REzolTM C\&T reagent (Protech Technology Enterprise, Taipei, Taiwan) following the manufacturer's instructions. The RNA was reverse-transcribed using RevertAid RT Reverse Transcription kit (Thermo Fisher Scientific Inc., Waltham, MA, USA). Real-time qPCR of interest gene was performed with HD 2X SYBR GREEN qPCR MIX (Hong Da Life Science, Taipei, Taiwan) using the Applied Biosystems QuantStudio 7 Flex Real-Time qPCR System and Applied Biosystems Sequence Detection Systems (QuantStudio Software v1.3) software (Applied Biosystems, Waltham, MA, USA). Ribosomal $18 \mathrm{~S}$ was used as the endogenous control. The primers used in this study are listed in Table S2. The target gene relative to the $18 \mathrm{~S}$ reference gene was analyzed using the comparative ÄCt method.

\subsection{Immunohistochemistry (IHC) Staining}

Formalin-fixed heart tissue was paraffin-embedded and sectioned (0.5 ìm thickness). Sections were stained using anti- $\alpha$-smooth muscle actin ( $\alpha$-Sma, 1:500), anti-Collagen IV (Col IV, 1:500) or inducible nitric oxide synthase (iNOS, 1:200), and images were captured using Olympus BX51 microscope combined with Olympus DP72 camera and CellSens Standard 1.14 software (Olympus, Hamburg, Germany) or using TissueFAXS system (TissueGnostics, Vienna, Austria).

\subsection{Cell Culture and Treatment}

H9c2 cardiomyoblasts were purchased from the Bioresource Collection and Research Center (BCRC, Hsinchu, Taiwan), and then cultured in Dulbecco's modified essential medium (DMEM) supplemented with 10\% fetal bovine serum (Gibco, Brooklyn, NY, USA), $2 \mathrm{mM}$ glutamine, and 100 units/mLof penicillin and streptomycin. Cellular environment was maintained at $5 \% \mathrm{CO}_{2}$ at $37^{\circ} \mathrm{C}$ incubator. $\mathrm{H} 9 \mathrm{c} 2$ cells were pre-treated with AD-9308 for $1 \mathrm{~h}$ and then incubated in medium containing fatty-acid-free bovine serum albumin (BSA)-conjugated palmitate $(0.1 \mathrm{mM})$ and high D-glucose $(33 \mathrm{mM})$ for $24-72 \mathrm{~h}$.

\subsection{Cell Counting Kit (CCK)-8 Assay}

H9c2 cardiomyoblasts were seeded at a density of $6 \times 10^{3}$ cells per well into a 96-well microplate and incubated for $24 \mathrm{~h}$. Following treatment, the cell viability was determined using CCK-8 assay (Dojindo Molecular Technologies, Kumamoto, Japan) according to the manufacturer's protocol. The absorbance value was detected at $450 \mathrm{~nm}$ using a microplate reader. The absorbance was normalized to cells incubated in control medium, which was taken as 100 .

\subsection{Measurement of ATP Level}

ATP level in cells was measured using ViaLight ${ }^{\mathrm{TM}}$ plus kit (Lonza, Basel, Switzerland) according to the manufacturer's protocol. Briefly, cells were incubated with lysis buffer for $10 \mathrm{~min}$ and the substrate was added for $2 \mathrm{~min}$. The absorbance value was detected using SpectraMax M5 ELISA plate reader (Molecular Devices, Silicon Valley, CA, USA).

\subsection{NF-kB Activity Assay}

To measure the activity of NF- $\mathrm{kB}$, cells were harvested after treatment, and nuclear lysates were extracted using the Nuclear Extraction kit (Abcam, Cambridge, UK), according to the manufacturer's protocol. The NF- $\mathrm{KB}$ activity in nuclear extract lysates was detected using the NF-kB transcription factor assay kit (Abcam, Cambridge, UK) according to the recommended experimental protocol. 


\subsection{Subcellular Fractionation}

After stimulation with indicated concentration of AD-9308, H9c2 cells were trypsinized, transferred to $15 \mathrm{~mL}$ tube, and washed with cold PBS. The protein was further fractionated using NE-PER Nuclear and Cytoplasmic Extraction Reagents (Thermo Scientific, Waltham, MA, USA) according to the manufacturer's instructions.

\subsection{4. $\mathrm{Ca}^{2+}$ Measurement}

Real-time intracellular levels of calcium were measured with a cell-permeable free$\mathrm{Ca}^{2+}$ fluorescent dye, Fura-2-AM, by a ratiometric imaging technique. After removal of culture media, H9c2 cells were loaded with $2 \mu \mathrm{M}$ Fura-2-AM in ExtraCellular buffer (ECB: $125 \mathrm{mM} \mathrm{NaCl}, 5 \mathrm{mMKCl}, 1.5 \mathrm{mM} \mathrm{MgCl}_{2}, 10 \mathrm{mM}$ glucose, and $1.5 \mathrm{mM} \mathrm{CaCl}_{2}, 20 \mathrm{mM}$ HEPES $\mathrm{pH}$ 7.4) containing $1 \mathrm{mM}$ probenecid and $0.04 \% \mathrm{~F} 127$ for $30 \mathrm{~min}$ at room temperature and then were washed twice with ECB.The detection of SR/ER Ca ${ }^{2+}$ content, $2 \mu \mathrm{M}$ thapsigargin was added to block $\mathrm{Ca}^{2+}$ uptake into SR/ER by inhibiting sarco/endoplasmic reticulum $\mathrm{Ca}^{2+}$-ATPase2 (SERCA2), and $1.5 \mathrm{mM}$ EGTA were added to chelate extracellular $\mathrm{Ca}^{2+}$. Fura-2-AM binds with intracellular $\mathrm{Ca}^{2+}$ of $\mathrm{H} 9 \mathrm{c} 2$ cells was detected using a fluorescence microscopy (Nikon Eclipse Ti microscope) by alternately exciting the cells at 340 and $380 \mathrm{~nm}$ every $300 \mathrm{~ms}$. Fluorescence intensities of cells were analyzed with the customized MATLAB script. Intracellular levels of calcium are present as F340/F380 ratio of Fura-2-AM.

\subsection{Mitochondrial Respiratory Chain Complex Activity Assay}

The mitochondrial complex spectrophotometric assays were carried out using published protocols [35]. Complex I and complex II activities were spectrophotometrically measured by examining the decrease in absorbance due to the reduction of 2,6- dichlorophenolindophenol (DCPIP) at $600 \mathrm{~nm}$. Complex III and complex IV-specific activities were measured by monitoring the reduction of oxidized cytochrome $\mathrm{C}$ and oxidation of reduced cytochrome $C$ at $550 \mathrm{~nm}$, respectively. Citrate synthase was spectrophotometrically measured by recording the increase in absorbance due to the reaction between $5^{\prime}, 5^{\prime}$-Dithiobis 2-nitrobenzoic acid (DTNB), and CoA-SH to form $\mathrm{TNB}^{2-}$ at $412 \mathrm{~nm}$. Relative mitochondrial complex activity was determined by comparison with complex activity of non-diabetic control mice.

\subsection{Measurements of Mitochondrial Functions}

The metabolic activities of cells were determined by measuring the oxygen consumption rate (OCR; indicative of mitochondrial oxidative respiration), using an XF24 extracellular flux analyzer (Seahorse Bioscience, North Billerica, MA, USA). H9c2 cells (6000 cells/well) were grown on Seahorse Bioscience Tissue Culture plates (Seahorse Bioscience, North Billerica, MA, USA). One hour prior to recording, the cell medium was replaced by DMEM containing $25 \mathrm{mM}$ glucose, $5 \mathrm{mM}$ pyruvate, and $2 \mathrm{mM}$ glutamine. Basal OCR (five measurements) was then measured using the Seahorse XF24-3 analyzer after equilibration and calibration according to the manufacturer's instructions.

\subsection{Statistical Analysis}

Data were expressed as mean \pm SEM. One-way ANOVA with trend test was employed to calculate $p$-for-trend among ordinal groups (Prism 8, GraphPad, San Diego, CA, USA). A $p$-value $<0.05$ was considered as statistically significant.

\section{Results}

\subsection{ALDH2 Activator, AD-9308, Ameliorated Diastolic Dysfunction in STZ-Induced Diabetic} Mice

Hyperglycemia was induced in 8-week-old C57BL6/J mice by STZ and mice were given 0 (water vehicle), 60 and $180 \mathrm{mg} / \mathrm{kg} /$ day of AD-9308 by daily oral gavage since the age of 10 weeks (Figure 1a). As expected, diabetic mice had lower body weight (Figure S1a) and higher fasting blood glucose level (Figure S1b) than non-diabetic control mice. 
Representative tracings of wave velocities obtained using pulse-wave and tissue Doppler are shown in Figure $1 \mathrm{~b}$. As can be seen, all diastolic parameters including E/A ratio, $\mathrm{e}^{\prime}$ wave, $\mathrm{E} / \mathrm{e}^{\prime}$ ratio, $\mathrm{e}^{\prime} / \mathrm{a}^{\prime}$ ratio, $\mathrm{E}$ wave deceleration time, and isovolumic relaxation time were impaired in STZ-induced diabetic mice, but showed dose-dependent improvement after treatment with AD-9308 (E/A ratio: $p$-for-trend $=0.0180, \mathrm{e}^{\prime}: p$-for-trend $=0.0002, \mathrm{E} / \mathrm{e}^{\prime}: p$-for-trend $=0.0202$, $\mathrm{e}^{\prime} / \mathrm{a}^{\prime}: p$-for-trend $=0.0019$, E wave deceleration time: $p$-for-trend $=0.0621$ and isovolumic relaxation time: $p$-for-trend $=0.0107$; Figure $1 \mathrm{c}-\mathrm{h}$ ). These findings revealed that diabetic related LV diastolic dysfunction could be restored by AD-9308 treatment.

\subsection{AD-9308 Ameliorated Systolic Dysfunction in STZ-Induced Diabetic Mice}

Representative tracings of M-mode echocardiography are shown in Figure 2a. STZinduced diabetic mice showed decreased fractional shortening, ejection fraction, stroke volume, and cardiac output. Systolic myocardial velocity, s wave (a systolic parameter measured by tissue Doppler), was also reduced in diabetic mice. Treatment of diabetic mice with AD-9308 improved all these systolic functions in a dose-dependent manner (fractional shortening: $p$-for-trend $=0.0055$, ejection fraction: $p$-for-trend $=0.0042$, stroke volume: $p$-for-trend $=0.0006$, cardiac output: $p$-for-trend $=0.0004$, and s wave: $p$-for-trend $=0.0167$, Figure $2 \mathrm{~b}-\mathrm{f})$.
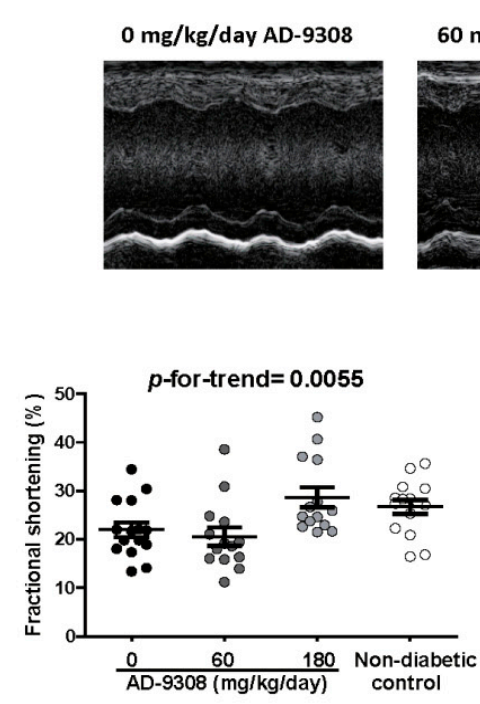

(b)

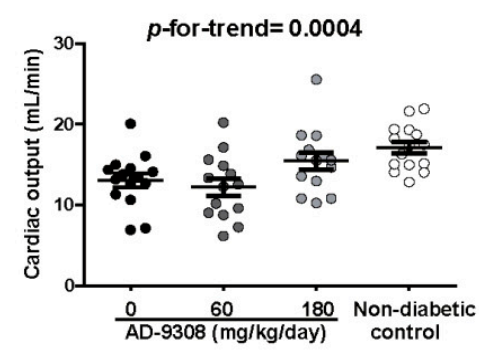

(e)
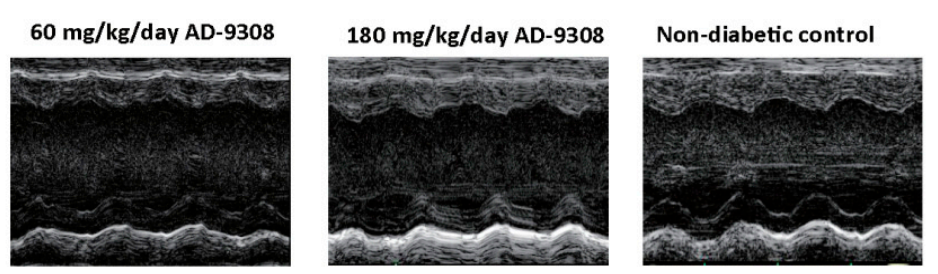

(a)

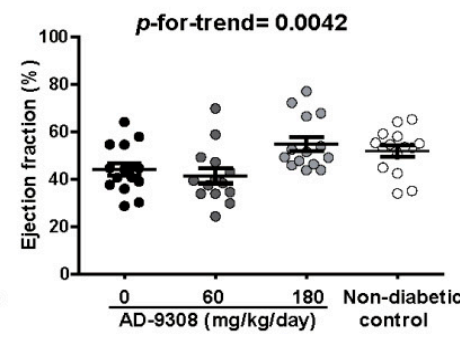

(c)

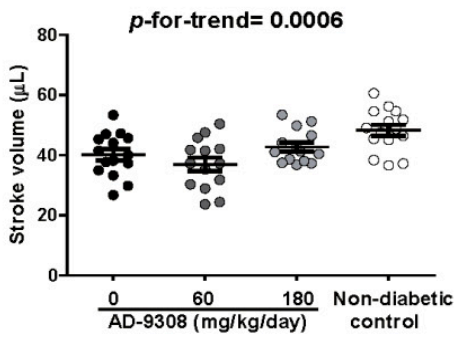

(d)

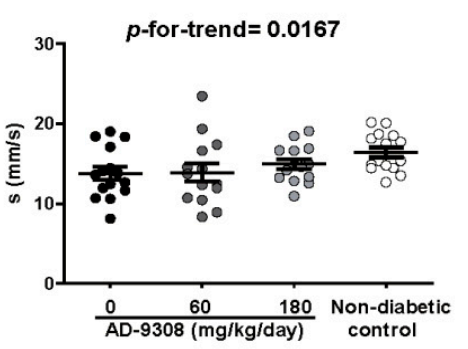

(f)

Figure 2. AD-9308 treatment improved left ventricular (LV) systolic dysfunction in streptozotocin (STZ)-induced diabetic mice. (a) representative M-mode echocardiograms. The mean (b) LV fraction shortening, (c) LV ejection fraction, (d) stroke volume, (e) cardiac output, and (f) s wave were measured in STZ-induced diabetic mice treated with 0,60, 180 mg/kg/day of AD-9308 by oral gavages and non-diabetic control mice. Data are presented as mean \pm SEM ( $n=14-16$ per group). $p$-for-trend was used to test the linear trend. 


\subsection{AD-9308 Partially Ameliorated LV Structural Changes in STZ-Induced Diabetic Mice}

As for LV morphology, M-mode echocardiography showed that AD-9308 treatment was associated with lower reductions of IVSd in a dose-dependent manner ( $p$-for-trend $=0.0022)$ in diabetic mice in comparison with non-diabetic control mice (Figure $3 a$ ). The reduction of $\mathrm{LV}$ mass in diabetic mice was also mitigated after AD-9308 treatment ( $p$-fortrend $=0.0015$; Figure $3 b$ ). However, other characteristics of heart geometry showed no significant difference between diabetic mice and non-diabetic control mice or AD-9308 treated diabetic mice (Figure $3 \mathrm{c}-\mathrm{g}$ ). Histological examination of myocardium revealed no significant difference in cardiomyocyte size between diabetic mice and non-diabetic control mice or AD-9308-treated diabetic mice (Figure $3 \mathrm{~h}$ and Figure S2).

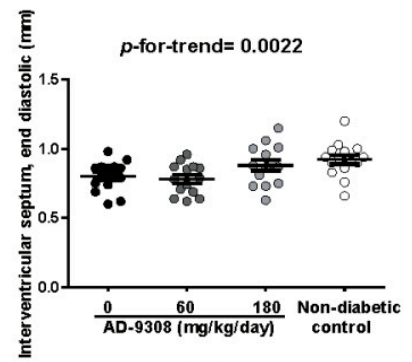

(a)

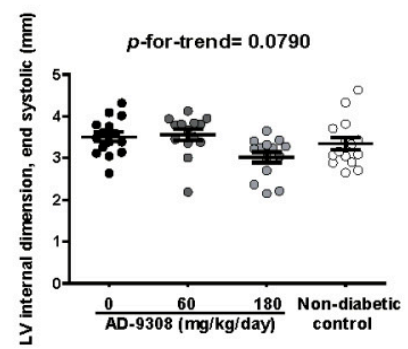

(e)

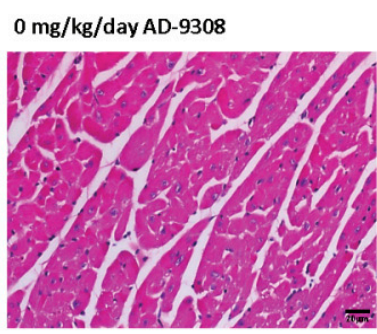

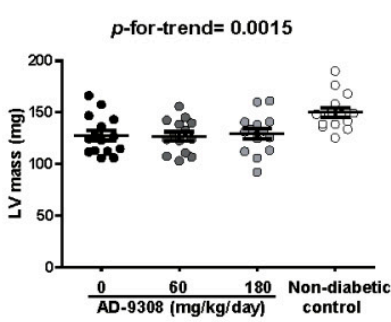

(b)

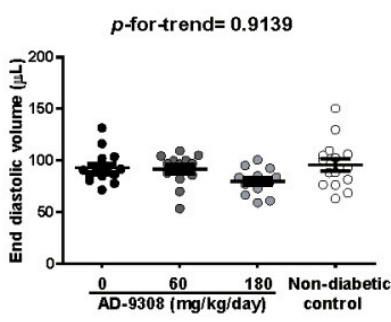

(f)

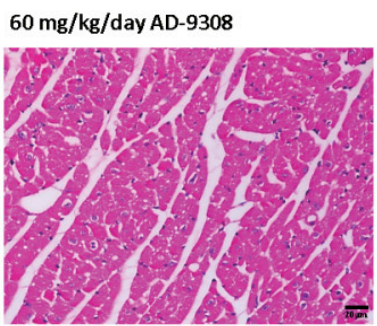

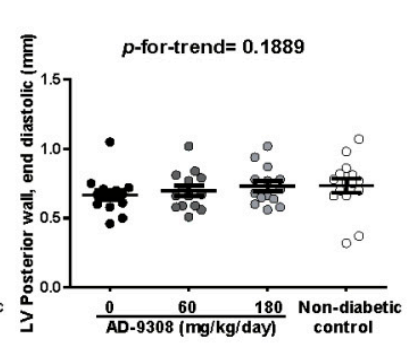

(c)

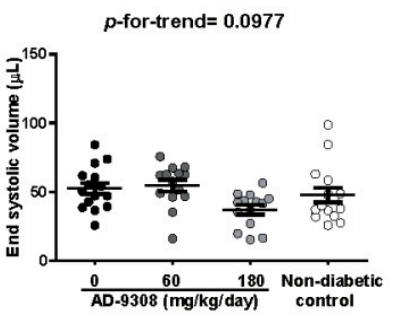

(g)
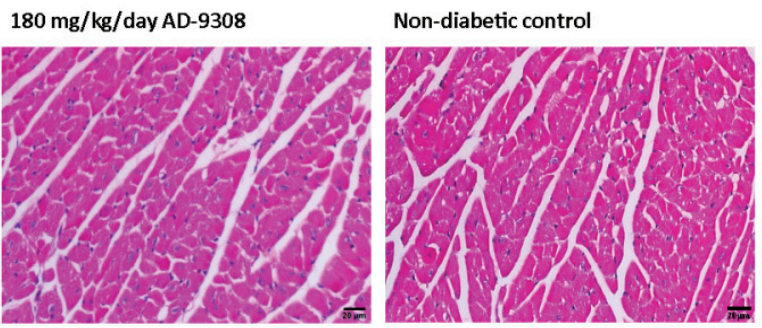

(h)

Figure 3. AD-9308 partially normalized cardiac morphology in streptozotocin (STZ)-induced diabetic mice. The mean (a) interventricular septum thickness at end diastole, (b) leftventricular (LV) mass, (c) LV posterior wall thickness at end diastole, (d) LV internal dimension at end diastole, (e) LV internal dimension at end systole, (f) LV end diastolic volume and (g) LV end systolic volume were measured in STZ-induced diabetic mice treated with 0,60,180 mg/ $\mathrm{kg} / \mathrm{day}$ of AD-9308 by oral gavages andnon-diabetic control mice, (h) representative hemotoxylin and eosin staining of heart sections from each group. Data are presented as mean $\pm \operatorname{SEM}(n=14-16$ per group). $p$-for-trend was used to test the linear trend. Scale bar, $20 \mu \mathrm{m}$.

\subsection{AD-9308 Treatment Decreased 4-HNE Level and Enhanced ALDH2 Activity}

AD-9308 drastically reduced serum 4-HNE level (Figure 4a) and 4-HNE protein adducts (Figure $4 \mathrm{~b}$ ) in cardiac tissue from diabetic mice. Consistent with previous results $[33,36]$, untreated diabetic mice had lower ALDH2 activity when compared with diabetic mice treated with AD-9308 and non-diabetic mice (Figure 4c). However, there 
was no difference in ALDH2 protein expression levels among groups (Figure S3). 4-HNE has been shown to trigger oxidative stress. Immunoblots revealed that AD-9308 treatment in diabetic mice lowered the expression of heme oxygenase 1 (Ho-1), a protein whose expression is induced in response to oxidative stress (Figure 4d). These data indicate that AD-9308 treatment in diabetic mice was effective in promoting the detoxification of 4-HNE through enhancing ALDH2 activity and alleviation of oxidative stress.

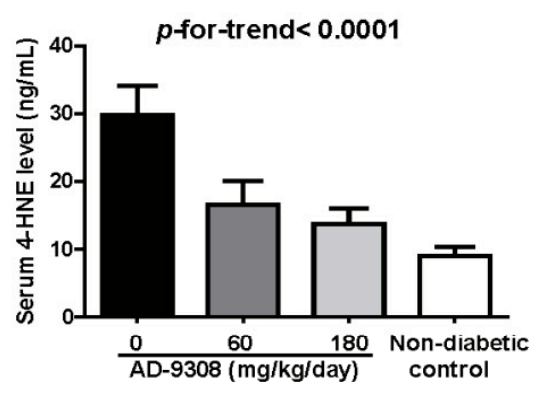

(a)

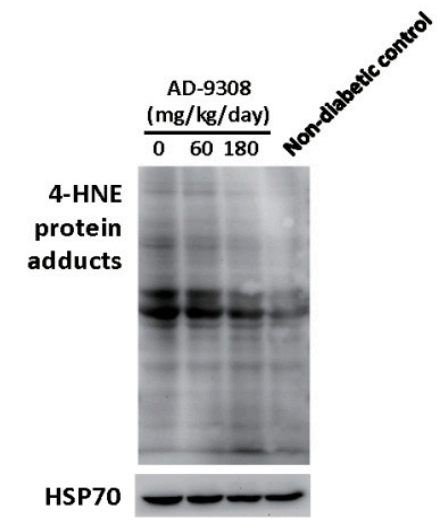

(b)

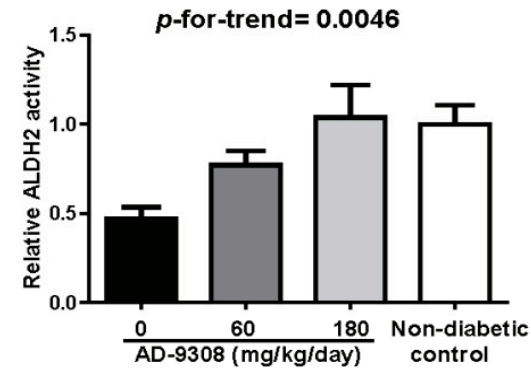

(c)

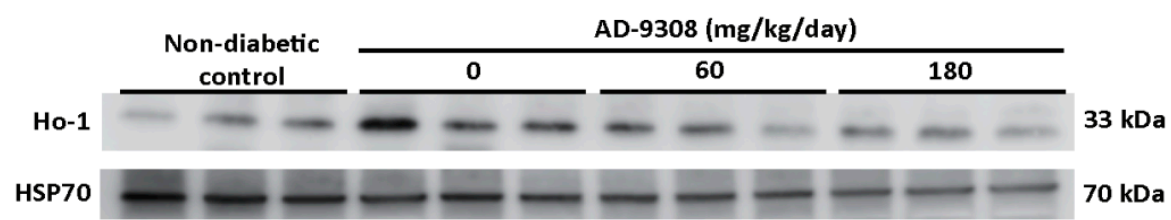

(d)

Figure 4. AD-9308 treatment reduced 4-hydroxy-2-nonenal (4-HNE) levels and enhanced aldehyde dehydrogenase 2 (ALDH2) activities to protect streptozotocin (STZ)-induceddiabetic mice against oxidative stress. (a) Serum 4-HNE levels, (b) 4-HNE protein adducts, (c) ALDH2 activities, and (d) heme oxygenase-1 (Ho-1) protein expressions of cardiac tissues were measured in STZ-induced diabetic mice treated with $0,60,180 \mathrm{mg} / \mathrm{kg} /$ day of AD- 9308 by oral gavages andnon-diabetic control mice. Data are presented as mean $\pm \operatorname{SEM}(n=6-12$ per group). $p$-for-trend was used to test the linear trend.

\subsection{AD-9308 Treatment Reduced Fibrosis of Diabetic Hearts}

Fibrosis and inflammation were reported to contribute to ventricular stiffness and dysfunction of diabetic cardiomyopathy [6]. AD-9308 treatment significantly reduced the expressions of fibrosis biomarkers including Tgf- $\beta 1$ ( $p$-for-trend $<0.0001$ ), Ctg $f$ ( $p$-for-trend $<0.0001$ ), fibroblast-specific protein 1 (Fsp1; $p$-for-trend $=0.0026)$, periostin (Postn; $p$-fortrend $=0.0046)$, fibronectin $(F n-1 ; p$-for-trend $=0.0001)$ and Tgf- $\beta 2$ ( $p$-for-trend $=0.0004)$ in a dose-dependent manner (Figure 5a-f) measured by RT-qPCR. On IHC stained sections, AD-9308 treatment decreased $\alpha$-Sma and Col IV deposition (Figure 5g,h). The $\alpha$-Sma and ColIV mRNA expression measured by RT-qPCR confirmed the results of IHC staining ( $p$-for-trend $=0.0367$ and 0.0113 , respectively) (Figure $5 \mathrm{i}, \mathrm{j}$ ). These results showed that AD-9308 treatment reduced myocardial fibrosis. 


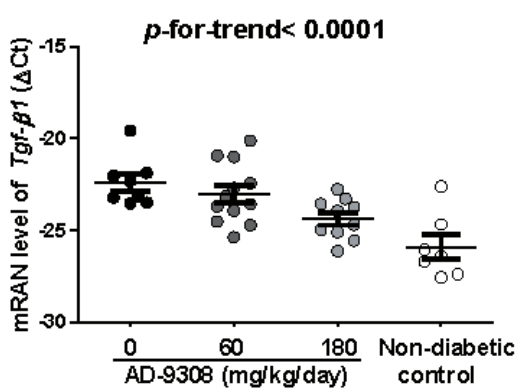

(a)

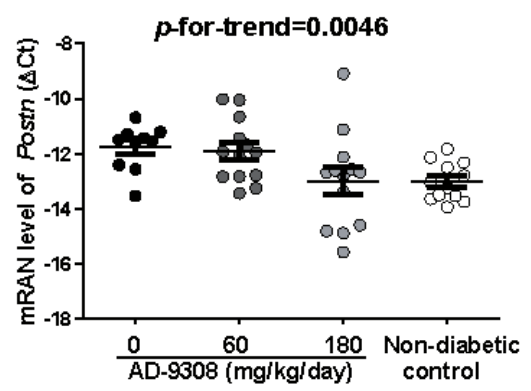

(d)

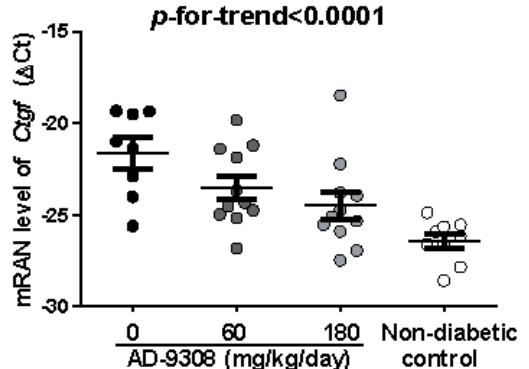

(b)

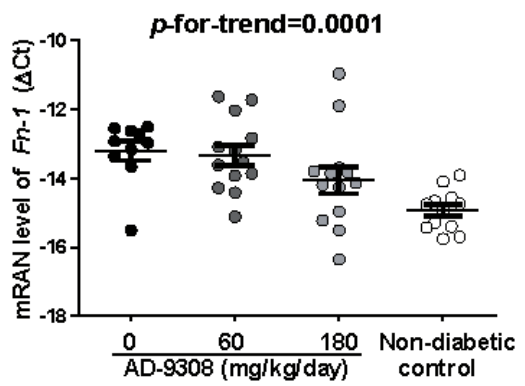

(e)

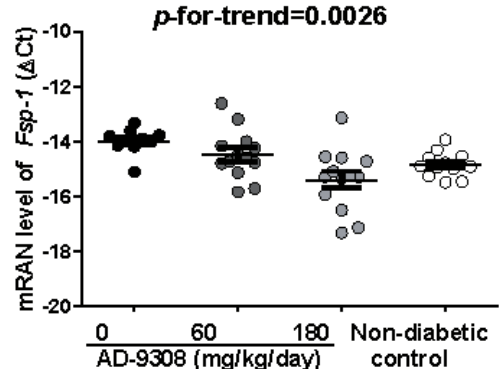

(c)

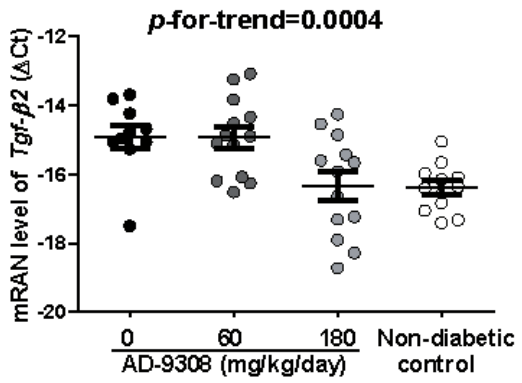

(f)

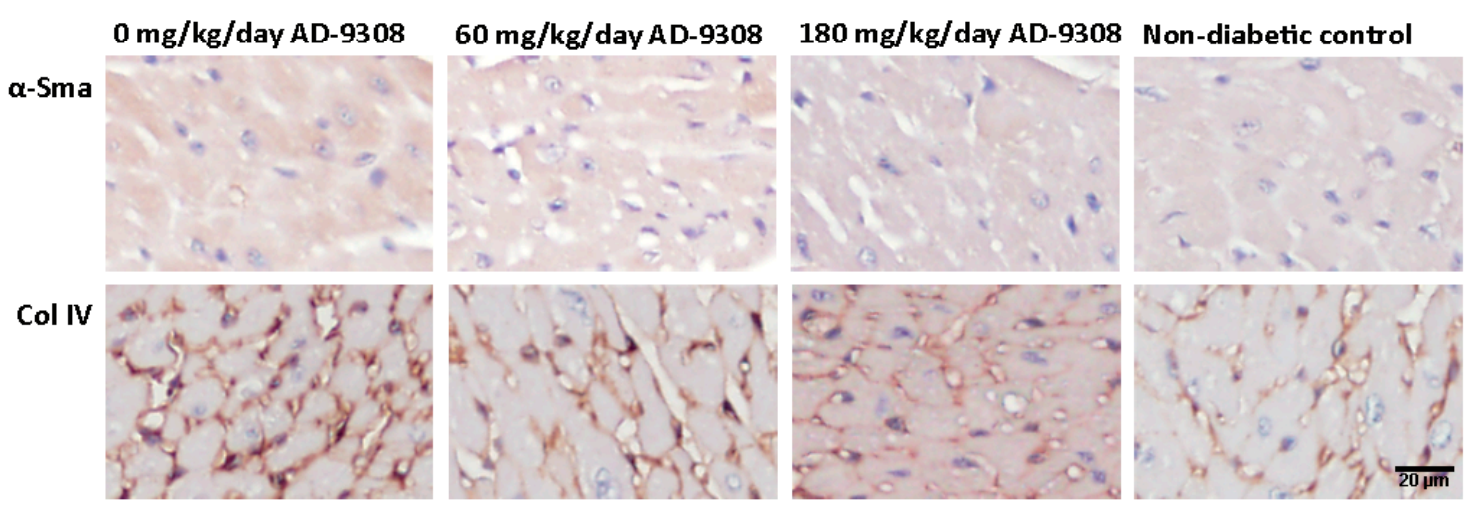

(g)

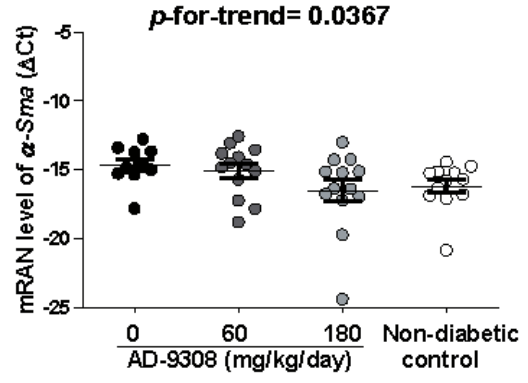

(h)

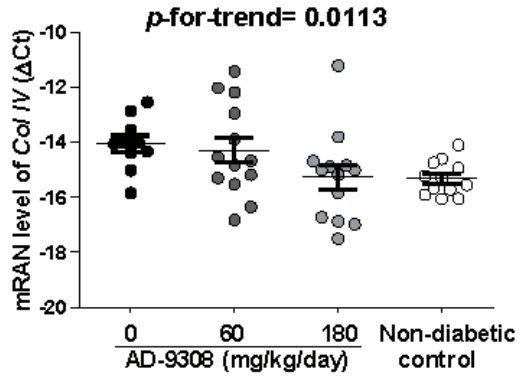

(i)

Figure 5. AD-9308 reduced cardiac fibrosis in streptozotocin (STZ)-induced diabetic mice. The mean mRNA levels of fibrosis markers, (a) transforming growth factor $\beta 1$ (Tgf- $\beta 1)$, (b) connective tissue growth factor (Ctgf), (c) fibroblast-specific protein 1 (Fsp1), (d) periostin (Postn), (e) fibronectin ( $F n-1)$, and (f) Tgf- $\beta 2$, and (g) representative immunohistochemical staining of anti- $\alpha$-smooth muscle actin ( $\alpha$-Sma)and anti-Collagen IV (Col IV) and mRNA levels of (h) $\alpha$-Sma and (i) Col IV were detected in cardiac tissuesfrom STZ-induced diabetic mice treated with $0,60,180 \mathrm{mg} / \mathrm{kg} /$ day of AD-9308 by oral gavages and non-diabetic control mice. Data are presented as mean $\pm \operatorname{SEM}(n=14-16$ per group). $p$-for-trend was used to test the linear trend. Scale bar, $20 \mu \mathrm{m}$. 


\subsection{AD-9308 Treatment Attenuated Inflammation and Apoptosis in Diabetic Hearts}

Apoptosis is a distinct feature of diabetic cardiomyopathy and strongly associated with inflammation. AD-9308 treatment reduced dose-dependently the mRNA expression of inflammatory markers including Il-1 $\beta$ ( $p$-for-trend $=0.0010), I l-6$ ( $p$-for-trend $=0.0002)$, interferon gamma (Inf $\gamma ; p$-for-trend $=0.0054)$, monocyte chemoattractant protein $1(M c p-1$; $p$-for-trend $=0.0047$ ), serum amyloid P-component (Sap; $p$-for-trend $=0.0005)$, and Tnf- $\alpha$ ( $p$-for-trend $<0.0001$ ) in the heart of diabetic mice (Figure 6a-f). Examining the protein levels of inflammation and apoptosis markers showed that AD-9308 treatment increased B-cell lymphoma 2 (Bcl-2) level, and reduced iNOS, Bcl-2-associated X protein (Bax) and cleaved caspase 3 (Casp3) levels, indicating attenuated inflammation and apoptosis in diabetic hearts (Figure 6g).

The effect of AD-9308 treatment on cell apoptosis under diabetic condition was further explored using the $\mathrm{H} 9 \mathrm{c} 2$ cardiomyoblast cell line. H9c2 cells were treated with a high level of glucose $(33 \mathrm{mM})$ combined with a high level of palmitate $(0.1 \mathrm{mM})$ to mimic the highglucose and high-palmitate serum levels of uncontrolled diabetic patients. High-glucose and high-palmitate treatment significantly reduced $\mathrm{H} 9 \mathrm{c} 2$ cell viability and ATP production after $72 \mathrm{~h}$ when compared with the controls (Figure 6h,i). Concordantly, pretreatment of AD-9308 exhibited elevated Bcl-2 expression, reduced Bax, and cleaved Casp3 protein expression in comparison with the controls (Figure 6j). These data indicated that AD-9308 preserved cell viability by inhibiting apoptosis of cardiac myoblasts.

$\mathrm{NF}-\mathrm{kB}$ is the major transcription factor responsible for regulating various pro-inflammatory cytokines. NF- $\mathrm{KB}$ is normally bound with its inhibitory factor I $\mathrm{KB}$ and sequestered in the cytosol [8]. Upon stimulation, I $\kappa \mathrm{B}$ is degraded and dissociated from the inactive cytoplasmic complex, thus facilitating the translocation of the active subunit NF- $\mathrm{KB}$ p65 into nuclear fraction and further transactivation of downstream genes. Our results showed that AD-9308 treatment increased the stability of I $\kappa \mathrm{B} \alpha$ protein in a dose-dependent manner. In addition, immunoblotting showed a decrease in NF- $\mathrm{BB}$ p65 nuclear translocation and reduced P65 reporter activity when treating diabetic mice with AD-9308 (Figure 6l,m). Altogether, our findings suggested that AD-9308 treatment attenuated myocardial inflammation and apoptosis.

3.7. AD-9308 Treatment Improved Mitochondrial Functions, Suppressed Autophagy and Calcium Handling in Diabetic Mice

Damaged mitochondrial functions in diabetic mice were previously reported [37]. Our study found a significant decrease in activities of complex II and complex III of mitochondrial electron transfer chain of the heart in diabetic mice when compared with non-diabetic control mice and AD-9308-treated diabetic mice (Figure 7a). To detect the rate of mitochondrial respiration, oxygen respiration rate (OCR) was measured using $\mathrm{H} 9 \mathrm{c} 2$ cells. Under high-glucose and high-palmitate culture condition, AD-9308 treatment dose-dependently increased spare respiratory capacity, basal and maximal respiration rates, and ATP production in comparison with non-treated cells (Figure $7 \mathrm{~b}, \mathrm{c}$ ). 


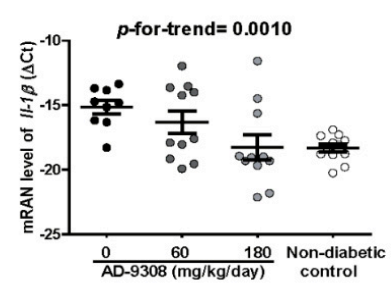

(a)

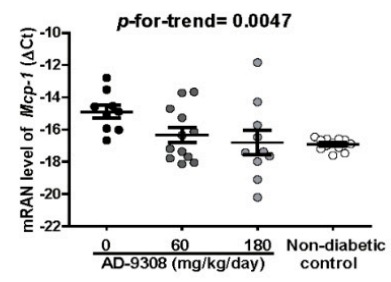

(d)

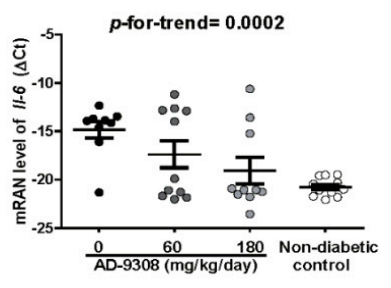

(b)

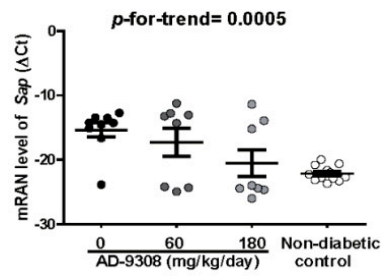

(e)

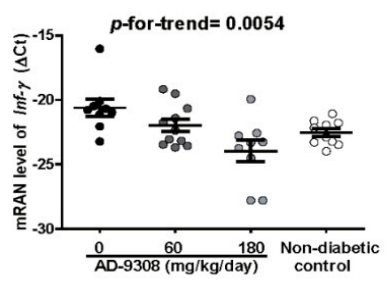

(c)

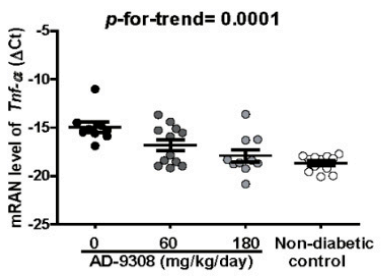

(f)

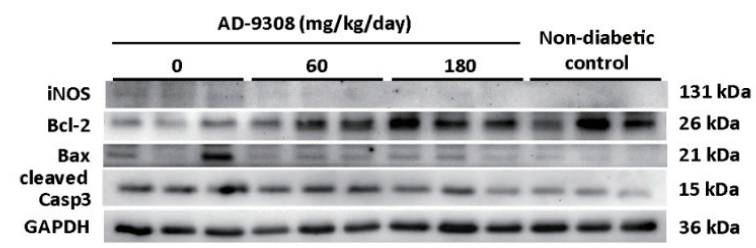

(g)

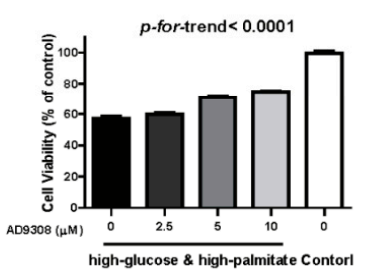

(h)

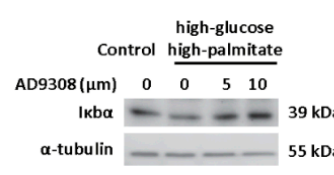

(k)

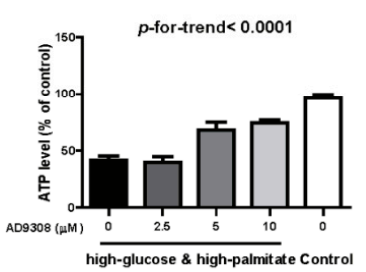

(i)

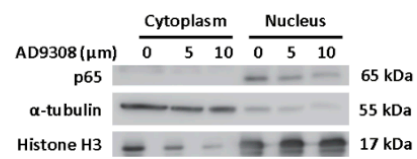

(I)

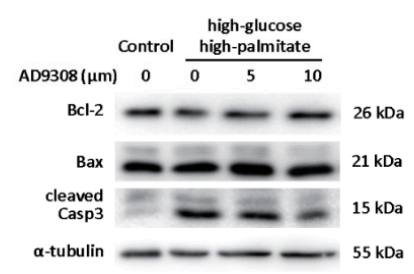

(j)

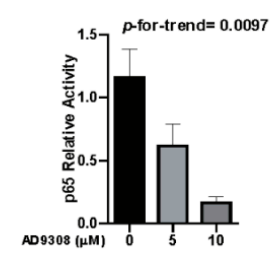

(m)

Figure 6. AD-9308 reduced inflammation in Streptozotocin (STZ)-induced diabetic mice and high-glucose and highpalmitate treated $\mathrm{H} 9 \mathrm{c} 2$ cardiomyoblasts. In cardiac tissues from STZ-induced diabetic mice treated with 0, 60, $180 \mathrm{mg} / \mathrm{kg} /$ day of AD-9308 by oral gavages and non-diabetic control mice, the levels of mRNA transcripts of genes coding inflammation markers, including (a) interleukin 1 $\beta(I l-1 \beta),(\mathbf{b})$ Il-6, (c) interferon gamma (Inf $\gamma)$, (d) monocyte chemoattractant protein 1 (Mcp-1), (e) serum amyloid P-component (Sap), (f) tumor necrosis factor- $\alpha$ (Tnf- $\alpha)$, and (g) the immunoblottings of inflammation marker, inducible nitric oxide synthase (iNOS), and apoptosis markers, including B-cell lymphoma 2 (Bcl-2), Bcl-2-associated X protein (Bax) and cleaved caspase 3 (Casp3) protein expressions were detected. Data are presented as mean \pm SEM ( $n=14-16$ per group). Relative (h) cell survival and (i) ATP production were measuredin 72-hhigh-glucose and high-palmitate incubated H9c2 cells without or with 1-h AD-9308 pretreatment. Immunoblottingsof (j) apoptotic markers (Bcl-2, Bax and cleaved Casp3), (k) inflammatory marker (Ikb $\alpha)$ and (1) fractionated cytosolic and nuclear proteins of NF- $\mathrm{B}$ p 65 (using $\alpha$-Tubulin and Histone $\mathrm{H} 3$ as cytosolic and nuclear internal controls, respectively) were measured in 72-hhigh-glucose and high-palmitate incubated H9c2 cells without or with 24-h AD-9308 pretreatment. (m) The mean NF-кB p65 reporter activity was measured in 72-hhigh-glucose and high-palmitate incubated H9c2 cells without or with 1-h AD-9308 pretreatment. Data are presented as mean \pm SEM ( $n=3-4$ per group). $p$-for-trend was used to test the linear trend. 


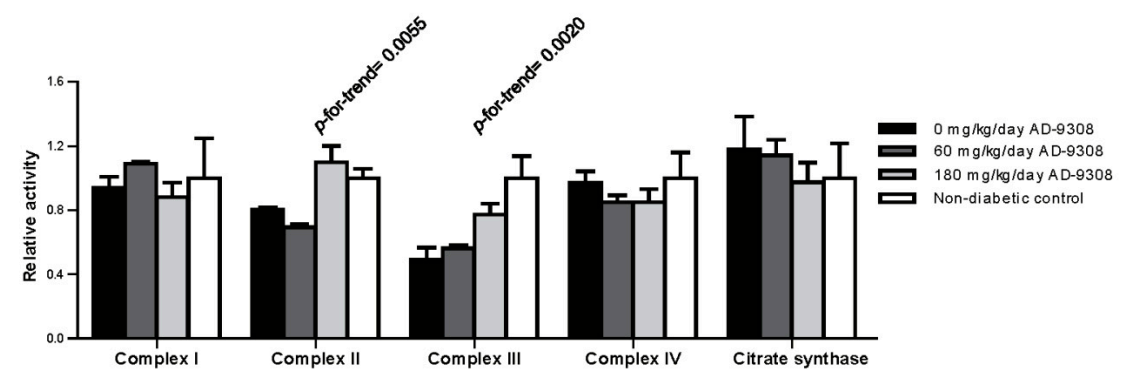

(a)

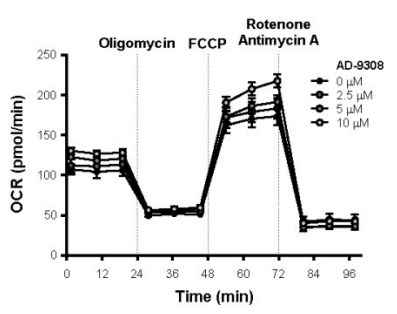

(b)

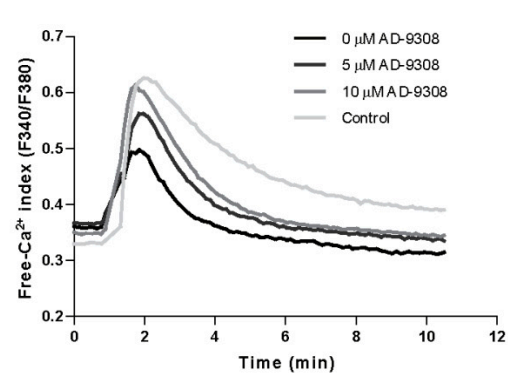

(d)

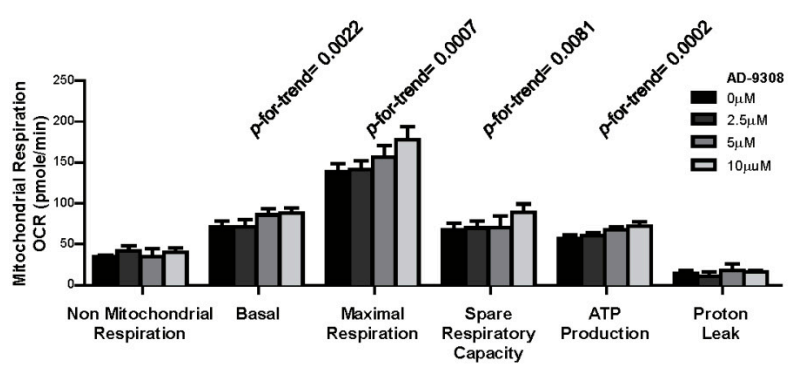

(c)

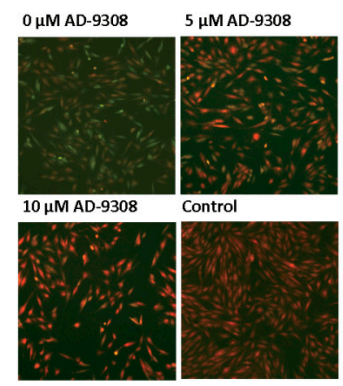

(e)

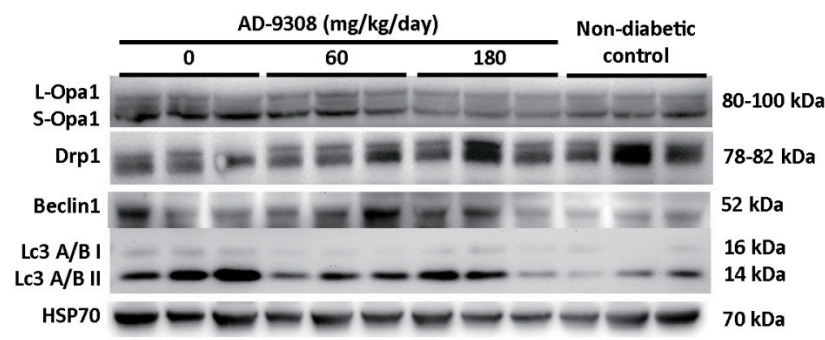

(f)

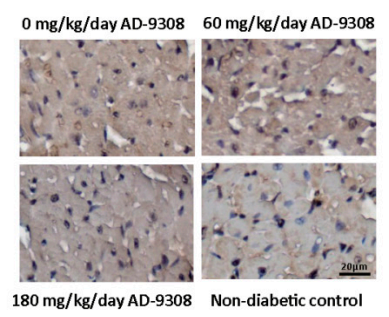

(g)

Figure 7. AD-9308 improved mitochondrial functions and calcium homeostasis in streptozotocin (STZ)-induced diabetic mice and high-glucose and high-palmitate treated $\mathrm{H} 9 \mathrm{c} 2$ cardiomyoblasts. (a) The activities of mitochondrial electron transfer chain complex were measured in cardiac tissue from STZ-induced diabetic mice treated with 0,60, $180 \mathrm{mg} / \mathrm{kg} / \mathrm{day}$ of AD-9308 by oral gavages and non-diabetic mice; (b) Mitochondrial respiration and (c) mitochondrial oxygen consumption rate in high-glucose and high-palmitate cultured H9c2 cells without or with AD-9308 treatment were measured. Data are presented as mean \pm SEM ( $n=3-6$ per group). $p$-for-trend was used to test the linear trend. (d) Fluorescence spectra from Fura-2-AM loaded H9c2 cells were analyzed under high-glucose and high-palmitate medium-cultured condition (pretreated with 0,5 , and $10 \mu \mathrm{M}$ AD-9308) and normal condition (control), and (e) represent Fura2-AM fluorescent images of free Ca ${ }^{2+}$ release from sacroendoplamic reticulum. (f) Immunoblottings of mitochondrial dynamic regulators, including long-form Optic atrophy 1 (L-Opa1), short-form Optic atrophy 1 (S-Opa1) and dynamin-related protein 1 (Drp1), and autophagy regulators, including Beclin1and Microtubule-associated proteins 1A/1B light chain 3A and 3B (LC3A/B) protein I and II, protein expressions and (g) representative immunohistochemical staining of LC3 were detected in cardiac tissue from STZ-induced diabetic mice treated with $0,60,180 \mathrm{mg} / \mathrm{kg} /$ day of AD-9308 by oral gavages and non-diabetic control mice. 
Furthermore, diabetic cardiomyopathy is characterized by reduced SR/ER $\mathrm{Ca}^{2+}$ content which may influences myocardial contractility $[38,39]$. Therefore, we measured SR/ER $\mathrm{Ca}^{2+}$ content in H9c2 cells and the effect of AD-9308 on SR/ER Ca ${ }^{2+}$ content. Cells were first incubated in Fura-2-AM, a cell-permeable fluorescent dye, which binds to cytosolic free $\mathrm{Ca}^{2+}$. Figure 7d showed the initial basal level of cytosolic free $\mathrm{Ca}^{2+}$.

Then, thapsigargin, a SERCA inhibitor, was added to block $\mathrm{Ca}^{2+}$ uptake into SR/ER. Therefore, $\mathrm{SR} \mathrm{Ca}{ }^{2+}$ were released from into cytosol, causing a transient surge in cytosolic free $\mathrm{Ca}^{2+}$ level, which returned to normal levels after $10 \mathrm{~min}$ of exposure. (Figure 7d). The peak value of thapsigargin-induced SR/ER $\mathrm{Ca}^{2+}$ release to cytosol was used as an index for SR/ER $\mathrm{Ca}^{2+}$ content. Under high-glucose and high-palmitate culture condition, the $\mathrm{SR} / \mathrm{ER} \mathrm{Ca}^{2+}$ content in H9c2 cells was reduced. AD-9308 treatment rescued the SR/ER $\mathrm{Ca}^{2+}$ content in a dose-dependent manner. Figure 7e showed the fluorescent signal of cytosolic $\mathrm{Ca}^{2+}$ level released from SR/ER corresponding to the signal peak in Figure 7d.

Oxidative stress in diabetic cardiomyopathy could result in damage to cellular organelles [40]. Recent studies showed that mitochondrial fusion/fission dynamics play an important role in response to mitochondrial damage [41-44]. Diabetic mice were found to exhibit higher protein levels of Drp1 (dynamin-related protein 1) and lower protein levels of Opa1 (Optic atrophy 1) when compared with non-diabetic control mice, indicating enhanced mitochondrial fission and suppressed fusion in diabetic heart, which was reversed by AD-9308 treatment (Figure 7f). The immunoblotting of Opa1 showed 2 major isoforms, long Opa1 forms (L-Opa1) and short forms (S-Opa1). The protein expression levels of L-Opa1showed no difference among diabetic mice, diabetic mice with AD-9308 treatment and non-diabetic control mice. However, the protein expression levels of S-Opa1showed an increased accumulation in diabetic mice when compared with diabetic mice with AD-9308 treatment and non-diabetic control mice. This imbalanced Opa1 processing was reported to cause heart failure in mice [45]. The autophagy system is a degradation pathway for cells to turn over organelles, which is required for maintaining normal cardiac functions [46,47]. The autophagy markers, Beclin 1, and microtubule-associated proteins $1 \mathrm{~A} / 1 \mathrm{~B}$ light chain 3A and 3B (LC3A/B) II showed increased protein expression levels in untreated diabetic heart, implying activation of autophagy, possibly related to injured organelles in diabetic hearts. AD-9308 treatment lowered these makers of autophagy, suggesting that AD-9308 might ameliorate organelle damage (Figure $7 \mathrm{f}$ ).

These above-mentioned findings evidenced impaired mitochondrial respiration, and mitochondrial dynamic and calcium handling in diabetic mice could be reversed by AD-9308.

\section{Discussion}

This study demonstrated that AD-9308 treatment protected diabetic mice from heart failure through restoration of ALDH2 activity and reduction of the 4-HNE level in STZinduced diabetic cardiomyopathy. AD-9308 treatment ameliorated both diastolic and systolic dysfunctions and reversed ventricular wall remodeling of diabetic hearts. AD-9308 treatment reduced fibrosis, inflammation, and apoptosis, improved mitochondrial respiration and calcium handling, and reduced autophagy in cardiac tissues of diabetic mice.

Recent studies have reported biological roles of ALDH2 in ischemic heart, diabetic cardiomyopathy, and cardiac aging [28,48,49]. Increased oxidative stress from elevated toxic aldehydes has been implicated as the key mediator of these cardiac impairments. Chronic hyperglycemia and elevated fatty acid in diabetes induce oxidative stress in diabetic hearts [50,51]. 4-HNE is a toxic aldehyde generated from peroxidation of polyunsaturated fatty acids of cell membrane when attacked by oxidative stress. 4-HNE is highly bioreactive toward proteins by forming covalent adducts, thus causing cellular damage [23,31]. 4-HNE is metabolized by aldehyde dehydrogenases to non-toxic HNEAcid. Indeed, diabetic patients were found to have elevated 4-HNE serum levels and increased 4-HNE protein adducts in the myocardium [52,53]. In our STZ-induced diabetic mice model, 4-HNE level and 4-HNE protein adducts were elevated while ALDH2 activity was lowered in diabetic hearts. We also demonstrated reduction of ejection fraction, fractional shortening, and 
stroke volume, decrease in E/A ratio, increase in E/e' ratio, and ventricular wall thinning, compatible with systolic and diastolic cardiac dysfunctions, and ventricular remodeling in diabetic mice as previously reported [6,53-55]. Administration of AD-9308 restored ALDH2 activity in cardiac tissues and significantly lowered 4-HNE levels, accompanied with reversal of diastolic and systolic functions as well as ventricular remodeling in a dose-dependent manner.

The present results were consistent with previous findings showing that ALDH2 prevented hyperglycemia-induced cellular dysfunctions in diabetic mice [37,56]. During disease progression of diabetes, ALDH2 activity reduced while the 4-HNE level increased [57]. Increased ALDH2 activity could reduce $4-H N E$ protein adducts [58,59]. An administration of AD-9308 significantly lowered Ho-1 protein expression, a stress protein induced upon oxidative stress, indicating amelioration of oxidative stress in diabetic micetreated with AD-9308.

Fibrosis is known as the first stage of diabetic cardiomyopathy [60]. Fibrosis biomarkers, including TGF- $\beta 1$, TGF- $\beta 2$, and CTGF as fibrosismarkers, and FSP1, POSTEN, and FN-1 as tissue remodeling markers have been systematically examined [61,62]. We found that the expressions of these genes were all increased in diabetic hearts. Moreover, IHC showed increased collagen disposition in the myocardium of STZ-induced diabetic mice. As inflammatory response was reported to increase cardiac oxidative stress and induce fibrosis in diabetic mice [48,63], inflammatory gene expression in our model was measured. We foundthat increased mRNA expressions of several pro-inflammatory genes including Il-1 $\beta$ and Il-6, Mcp-1, Tnf- $\alpha$ and Inf $\gamma$, as well as an inflammation functional predecessor Spa in diabetic mice, in agreement with previous results [54,64,65].

Inflammation was reported to stimulate apoptosis in diabetic cardiomyopathy [66]. In general, the rate of apoptosis in the myocardium is very low $(0.001$ to $0.002 \%)$ but becomes elevated in diabetic patients. Increased apoptosis causes myocardial dysfunctions [67]. Increase in Casp3, a central executioner of apoptosis, was observed in LV tissue obtained from the failing human hearts [68]. Consistently, we found increased Caspase-3, increased Bcl-2 (an inhibitor of apoptosis), and reduced Bax (an activator of apoptosis) expression in diabetic heart, which could be as reversed by AD-9308 treatment, consistent with previous studies [58,69-71].

Furthermore, previous results showed reduction of mitochondrial complex activities in diabetic mice. Similar mitochondrial dysfunction was also recapitulated in our highglucose and high-palmitate treated cardiac myoblast cell line model. 4-HNE was reported to dampen the electron transport chainof cardiomyocytes from humans and rats with heart failure [72-74] and was found to form adducts with mitochondrial complex II protein in diabetic hearts [75]. On the other hand, ALDH2 activation was reported to protect mitochondrial functions of the myocardium and inhibit ALDH2-aggravated mitochondrial impairment indiabetic rats $[33,36]$. In addition, our findings showed an impairment of $\mathrm{Ca}^{2+}$ handling in H9c2 cells under high-glucose and high palmitate culture condition, which could be partially rescued by AD-9308 treatment. Our results were in line with previous findings showing a decrease in SR/ER $\mathrm{Ca}^{2+}$ content in cardiomyopathy in STZ-induced diabetic rats $[39,76]$.

STZ-induced diabetic mice showed enhanced autophagy in diabetic cardiomyocytes. Since glucose and fatty acids cannot be effectively taken up in untreated diabetic myocardium, energy deficit and cellular starvation activates autophagy [77-80]. In addition, autophagy is also triggered by organelle damage. We found increased autophagy marker expression in diabetic hearts, which is reduced by AD-9308 treatment.

Treatment of diabetic cardiomyopathy remains an unmet medical need. In earlier studies on diabetic cardiomyopathy, chronic metformin treatment was reported to restore autophagic activity and inhibit cardiomyocyte apoptosis in OVE26 diabetic mice [78]. Administration of neuregulin-1 (rhNRG-1) in STZ-induced diabetic rats reduced cell apoptosis and fibrosis as well as ameliorated hypertension [70]. Inhibition of mitochondrial fission with Drp1 inhibitor melatonin was also shown to suppress oxidative stress and alleviate 
mitochondrial dysfunction and cardiac systolic dysfunction in diabetic mice [41]. However, few of them were successfully translated into clinically approved therapy. AD-9308 is a novel, highly potent, selective, and water-soluble small-molecule ALDH2 activator, which has passed phase 1 human clinical trials with acceptable safety and tolerability in healthy subjects. Our findings may be translated into clinical trials and eventually clinical use soon.

Our study has some limitations. First, ALDH2 is ubiquitously expressed. However, we only explore myocardium, leaving other organs unexplored. Indeed, 4-HNE has been shown to oxidize LDL and promote oxLDL accumulation in atherosclerotic plaques in vessels [81,82]. 4-HNE also induced ER stress in endothelial cells [83]. ER stress exerts a negative effect on endothelial cell stability [84]. Endothelial dysfunction may increase arterial stiffness and resistance and cause myocardial hypertrophy. Therefore, the effect of ALDH2 activation might be through a secondary effect from other cells in addition to the myocardium and the cardiac myocytes as characterized in this study.

\section{Conclusions}

Diabetic cardiomyopathy induced through hyperglycemia and oxidative stress is one of the most severe complications in the progression of diabetes. The present study shows for the first time that ALDH2 activator AD-9308 improved cardiac diastolic and systolic functions as well as ventricular wall remodeling in STZ-induced diabetic mice. The results suggest that restoration of ALDH2 activity by AD-9308 can reduce oxidative stress through detoxification of 4-HNE, leading to suppressed fibrosis, inflammation, apoptosis, and autophagy, and improved mitochondrial functions and calcium dynamics in diabetic cardiomyocytes (Figure 8). Our findings highlighted a new therapeutic approach to treat diabetic cardiomyopathy through scavenging toxic aldehydes.

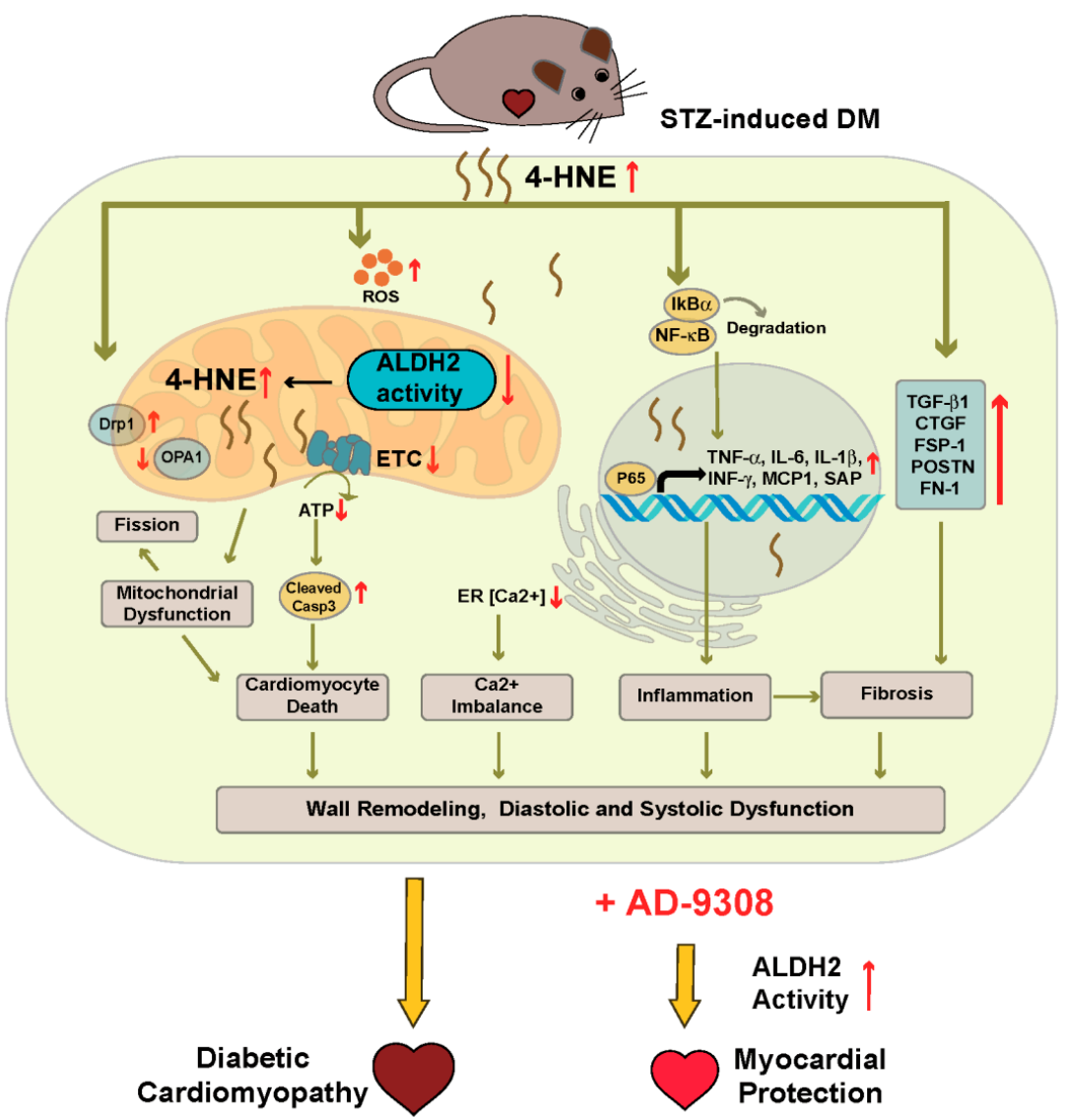

Figure 8. Schematic diagram depicting the effect of AD-9308 treatment on diabetic mice. 
Supplementary Materials: The following are available online at https:/ / www.mdpi.com/2076-3 921/10/3/450/s1, Figure S1: Characterization of the streptozotocin-induced diabetic mice with AD-9308 treatment, Figure S2: Cardiomyocyte size of the streptozotocin (STZ)-induced diabetic mice with AD-9308 treatment, Figure S3: ALDH2 protein expression levels of the streptozotocin (STZ)-induced diabetic mice with AD-9308 treatment, Table S1: Primary antibodies used in this study, Table S2: RT-qPCRprimer sequences used in this study.

Author Contributions: Conceptualization, Y.-C.C., L.-M.C., C.-H.C. and D.M.-R.; methodology, H.L.L., S.-W.H., C.-F.H. and Y.-C.C.; software, Y.-C.L. and F.-C.T.; validation, H.-L.L., S.-W.H., C.-F.H., Y.-C.C. and L.-M.C.; formal analysis, H.-L.L., S.-W.H., C.-F.H. and Y.-C.C.; investigation, H.-L.L., S.-W.H., J.-Y.H., Y.-L.L., C.-N.H., J.-J.H., S.-M.C., Z.-Z.D., T.-Y.L., Y.-C.L., W.-L.S., L.-Y.C. and M.-L.H.; resources, W.Y. and F.-C.T.; data curation, H.-L.L. and S.-W.H.; writing-original draft preparation, H.-L.L., S.-W.H. and C.-F.H.; writing-review and editing, Y.-C.C. and L.-M.C.; visualization, H.-L.L., S.-W.H. and C.-F.H.; supervision, Y.-C.C. and L.-M.C.; project administration, H.-L.L., Y.-C.C. and L.-M.C.; funding acquisition, J.-J.H., Y.-C.C. and L.-M.C. All authors have read and agreed to the published version of the manuscript.

Funding: This research was funded by the Ministry of Science and Technology of Taiwan, grants number MOST 105-2314-B-002-105-MY3, and by National Taiwan University Hospital Yunlin Branch, grants number NTUHYL109.S013 and NTUHYL107.S004. The APC was funded by Diabetes Association of Taiwan.

Institutional Review Board Statement: Experiments were performed on C57BL6/J mice according to National Ethical guidelines and were approved by the Institutional Animal Care and Use Committee of the Medical College of National Taiwan University (Ethical approval number: IACUC 20200046), which is accredited by the Association for Assessment and Accreditation of Laboratory Animal Care International (AAALAC).

Informed Consent Statement: Not applicable.

Data Availability Statement: The data presented in this study are available on request from the corresponding author.

Acknowledgments: We are grateful to the Microscopy Core Facility, RCF3 and RCF7 at Department of Medical Research of National Taiwan University Hospital, and the Molecular Imaging Center and the Genomic and Precision Medicine Center at National Taiwan University for providing the instrument and technical support during this study. We also thank Yung-Ching Wang for ultrasound technical support and Foresee Pharmaceuticals Co., Ltd., Taiwan for the provision of AD-9308. Both D.M.-R. and C.-H.C. were supported by the National Institute of Health, Bethesda, MD, USA. Award AAA11147 to D.M.-R. at Stanford University, School of Medicine, Stanford, CA, USA.

Conflicts of Interest: D.M.-R., C.-H.C., and W.Y. are co-inventors of several issues' patents on "Modulators of aldehyde dehydrogenase activity and methods of use thereof", patent Numbers: US 10227304, US 9670162, US 9370506, US 9345693, US 8906942, US 8772295, US 8389522, and US 8354435. W.Y. is an employee and shareholder of Foresee Pharmaceuticals Co. Ltd. W.Y. is a co-inventor of issued patent US 9879036 "Modulators of aldehyde dehydrogenase activity and methods of use thereof". Other authors declared no competing interests.

\section{References}

1. Saeedi, P.; Petersohn, I.; Salpea, P.; Malanda, B.; Karuranga, S.; Unwin, N.; Colagiuri, S.; Guariguata, L.; Motala, A.A.; Ogurtsova, K.; et al. Global and regional diabetes prevalence estimates for 2019 and projections for 2030 and 2045: Results from the International Diabetes Federation Diabetes Atlas, 9th edition. Diabetes Res. Clin. Pract. 2019, 157, 107843. [CrossRef]

2. Rask-Madsen, C.; King, G.L. Vascular Complications of Diabetes: Mechanisms of Injury and Protective Factors. Cell Metab. 2013, 17, 20-33. [CrossRef]

3. Kannel, W.B.; Hjortland, M.; Castelli, W.P. Role of diabetes in congestive heart failure: The Framingham study. Am. J. Cardiol. 1974, 34, 29-34. [CrossRef]

4. Dauriz, M.; Mantovani, A.; Bonapace, S.; Verlato, G.; Zoppini, G.; Bonora, E.; Targher, G. Prognostic Impact of Diabetes on Long-term Survival Outcomes in Patients With Heart Failure: A Meta-analysis. Diabetes Care 2017, 40, 1597-1605. [CrossRef]

5. Rubler, S.; Dlugash, J.; Yuceoglu, Y.Z.; Kumral, T.; Branwood, A.W.; Grishman, A. New type of cardiomyopathy associated with diabetic glomerulosclerosis. Am. J. Cardiol. 1972, 30, 595-602. [CrossRef]

6. Jia, G.; Hill, M.A.; Sowers, J.R. Diabetic Cardiomyopathy: An Update of Mechanisms Contributing to This Clinical Entity. Circ. Res. 2018, 122, 624-638. [CrossRef] [PubMed] 
7. Murtaza, G.; Virk, H.U.H.; Khalid, M.; Lavie, C.J.; Ventura, H.; Mukherjee, D.; Ramu, V.; Bhogal, S.; Kumar, G.; Shanmugasundaram, M.; et al. Diabetic cardiomyopathy-A comprehensive updated review. Prog. Cardiovasc. Dis. 2019, 62, 315-326. [CrossRef] [PubMed]

8. Ghosh, N.; Katare, R. Molecular mechanism of diabetic cardiomyopathy and modulation of microRNA function by synthetic oligonucleotides. Cardiovasc. Diabetol. 2018, 17, 43. [CrossRef] [PubMed]

9. Tan, Y.; Zhang, Z.; Zheng, C.; Wintergerst, K.A.; Keller, B.B.; Cai, L. Mechanisms of diabetic cardiomyopathy and potential therapeutic strategies: Preclinical and clinical evidence. Nat. Rev. Cardiol. 2020, 17, 585-607. [CrossRef] [PubMed]

10. Regan, T.J.; Lyons, M.M.; Ahmed, S.S.; Levinson, G.E.; Oldewurtel, H.A.; Ahmad, M.R.; Haider, B. Evidence for Cardiomyopathy in Familial Diabetes Mellitus. J. Clin. Investig. 1977, 60, 885-899. [CrossRef] [PubMed]

11. Boonman-de Winter, L.; Rutten, F.; Cramer, M.; Landman, M.; Liem, A.; Rutten, G.; Hoes, A. High prevalence of previously unknown heart failure and left ventricular dysfunction in patients with type 2 diabetes. Diabetologia 2012, 55, $2154-2162$. [CrossRef] [PubMed]

12. Bugger, H.; Abel, E.D. Rodent models of diabetic cardiomyopathy. Dis. Model. Mech. 2009, 2, 454-466. [CrossRef] [PubMed]

13. Rajesh, M.; Bátkai, S.; Kechrid, M.; Mukhopadhyay, P.; Lee, W.S.; Horváth, B.; Holovac, E.; Cinar, R.; Liaudet, L.; Mackie, K.; et al. Cannabinoid 1 Receptor Promotes Cardiac Dysfunction, Oxidative Stress, Inflammation, and Fibrosis in Diabetic Cardiomyopathy. Diabetes 2012, 61, 716-727. [CrossRef] [PubMed]

14. Pacher, P.; Rajesh, M.; Batkai, S.; Mukhopadhyay, P.; Lee, W.S.; Horvath, B.; Cinar, R.; Liaudet, L.; Mackie, K.; Haskó, G. Cannabinoid 1 receptor promotes cardiac dysfunction, oxidative stress, inflammation, and fibrosis in diabetic cardiomyopathy. FASEB J. 2013, 27 (Suppl. 1), 1128.10. [CrossRef]

15. Westermann, D.; Van Linthout, S.; Dhayat, S.; Dhayat, N.; Escher, F.; Spillmann, F.; Noutsias, M.; Riad, A.; Schultheiss, H.-P.; Bücker-Gärtner, C.; et al. Cardioprotective and Anti-Inflammatory Effects of Interleukin Converting Enzyme Inhibition in Experimental Diabetic Cardiomyopathy. Diabetes 2007, 56, 1834-1841. [CrossRef]

16. Westermann, D.; Rutschow, S.; Van Linthout, S.; Linderer, A.; Bücker-Gärtner, C.; Sobirey, M.; Riad, A.; Pauschinger, M.; Schultheiss, H.-P.; Tschöpe, C. Inhibition of p38 mitogen-activated protein kinase attenuates left ventricular dysfunction by mediating pro-inflammatory cardiac cytokine levels in a mouse model of diabetes mellitus. Diabetologia 2006, 49, $2507-2513$. [CrossRef]

17. Chiu, J.; Farhangkhoee, H.; Xu, B.Y.; Chen, S.; George, B.; Chakrabarti, S. PARP mediates structural alterations in diabetic cardiomyopathy. J. Mol. Cell. Cardiol. 2008, 45, 385-393. [CrossRef]

18. Ye, G.; Metreveli, N.S.; Donthi, R.V.; Xia, S.; Xu, M.; Carlson, E.C.; Epstein, P.N. Catalase protects cardiomyocyte function in models of type 1 and type 2 diabetes. Diabetes 2004, 53, 1336-1343. [CrossRef]

19. Kralik, P.M.; Ye, G.; Metreveli, N.S.; Shen, X.; Epstein, P.N. Cardiomyocyte Dysfunction in Models of Type 1 and Type 2 Diabetes. Cardiovasc. Toxicol. 2005, 5, 285-292. [CrossRef]

20. Lopaschuk, G.D.; Tahiliani, A.G.; Vadlamudi, R.; Katz, S.; McNeill, J. Cardiac sarcoplasmic reticulum function in insulin- or carnitine-treated diabetic rats. Am. J. Physiol. Heart Circ. Physiol. 1983, 245, H969-H976. [CrossRef]

21. Bugger, H.; Abel, E.D. Molecular mechanisms for myocardial mitochondrial dysfunction in the metabolic syndrome. Clin. Sci. 2008, 114, 195-210. [CrossRef]

22. Negre-Salvayre, A.; Coatrieux, C.; Ingueneau, C.; Salvayre, R. Advanced lipid peroxidation end products in oxidative damage to proteins: Potential role in diseases and therapeutic prospects for the inhibitors. Br. J. Pharmacol. 2008, 153, 6-20. [CrossRef] [PubMed]

23. Mali, V.R.; Palaniyandi, S.S. Regulation and therapeutic strategies of 4-hydroxy-2-nonenal metabolism in heart disease. Free Radic. Res. 2014, 48, 251-263. [CrossRef] [PubMed]

24. Dham, D.; Roy, B.; Gowda, A.; Pan, G.; Sridhar, A.; Zeng, X.; Thandavarayan, R.A.; Palaniyandi, S.S. 4-Hydroxy-2-nonenal, a lipid peroxidation product, as a biomarker in diabetes and its complications: Challenges and opportunities. Free Radic. Res. 2020, 18, 1-15. [CrossRef]

25. Zhao, Y.; Song, W.; Wang, Z.; Wang, Z.; Jin, X.; Xu, J.; Bai, L.; Li, Y.; Cui, J.; Cai, L. Resveratrol attenuates testicular apoptosis in type 1 diabetic mice: Role of Akt-mediated Nrf2 activation and p62-dependent Keap1 degradation. Redox Biol. 2018, 14, 609-617. [CrossRef] [PubMed]

26. Toyokuni, S.; Yamada, S.; Kashima, M.; Ihara, Y.; Yamada, Y.; Tanaka, T.; Hiai, H.; Seino, Y.; Uchida, K. Serum 4-Hydroxy-2Nonenal-Modified Albumin Is Elevated in Patients with Type 2 Diabetes Mellitus. Antioxid. Redox Signal. 2000, 2, 681-685. [CrossRef] [PubMed]

27. Mali, V.R.; Ning, R.; Chen, J.; Yang, X.-P.; Xu, J.; Palaniyandi, S.S. Impairment of aldehyde dehydrogenase-2 by 4-hydroxy-2nonenal adduct formation and cardiomyocyte hypertrophy in mice fed a high-fat diet and injected with low-dose streptozotocin. Exp. Biol. Med. 2014, 239, 610-618. [CrossRef] [PubMed]

28. Chen, C.H.; Budas, G.R.; Churchill, E.N.; Disatnik, M.H.; Hurley, T.D.; Mochly-Rosen, D. Activation of Aldehyde Dehydrogenase-2 Reduces Ischemic Damage to the Heart. Science 2008, 321, 1493-1495. [CrossRef]

29. Zhao, M.X.; Zhou, B.; Ling, L.; Xiong, X.Q.; Zhang, F.; Chen, Q.; Li, Y.H.; Kang, Y.M.; Zhu, G.Q. Salusin-beta contributes to oxidative stress and inflammation in diabetic cardiomyopathy. Cell Death Dis. 2017, 8, e2690. [CrossRef] 
30. Liu, M.; Verma, N.; Peng, X.; Srodulski, S.; Morris, A.; Chow, M.; Hersh, L.B.; Chen, J.; Zhu, M.H.; Netea, M.G.; et al. Hyperamylinemia Increases IL-1beta Synthesis in the Heart via Peroxidative Sarcolemmal Injury. Diabetes 2016, 65, $2772-2783$. [CrossRef]

31. Pan, G.; Deshpande, M.; Pang, H.; Palaniyandi, S.S. Precision medicine approach: Empagliflozin for diabetic cardiomyopathy in mice with aldehyde dehydrogenase (ALDH) $2 * 2$ mutation, a specific genetic mutation in millions of East Asians. Eur. J. Pharmacol. 2018, 839, 76-81. [CrossRef] [PubMed]

32. Srivastava, S.; Chandra, A.; Wang, L.F.; Seifert, W.E., Jr.; DaGue, B.B.; Ansari, N.H.; Srivastava, S.K.; Bhatnagar, A. Metabolism of the lipid peroxidation product, 4-hydroxy-trans-2-nonenal, in isolated perfused rat heart. J. Biol. Chem. 1998, 273, 10893-10900. [CrossRef] [PubMed]

33. Wang, J.; Wang, H.; Hao, P.; Xue, L.; Wei, S.; Zhang, Y.; Chen, Y. Inhibition of Aldehyde Dehydrogenase 2 by Oxidative Stress Is Associated with Cardiac Dysfunction in Diabetic Rats. Mol. Med. 2011, 17, 172-179. [CrossRef] [PubMed]

34. Yang, W.; Yu, Y.T.; Jiang, C. Mitochondrial Aldehyde Dehydrogenase-2 Binding Compounds and Methods of Use Thereof. U.S. Patent 9,879,036 B2, 30 January 2018.

35. Spinazzi, M.; Casarin, A.; Pertegato, V.; Salviati, L.; Angelini, C. Assessment of mitochondrial respiratory chain enzymatic activities on tissues and cultured cells. Nat. Protoc. 2012, 7, 1235-1246. [CrossRef]

36. Mali, V.R.; Pan, G.D.; Deshpande, M.; Thandavarayan, R.A.; Xu, J.; Yang, X.-P.; Palaniyandi, S.S. Cardiac Mitochondrial Respiratory Dysfunction and Tissue Damage in Chronic Hyperglycemia Correlate with Reduced Aldehyde Dehydrogenase-2 Activity. PLoS ONE 2016, 11, e0163158. [CrossRef]

37. Zhang, Y.; Babcock, S.A.; Hu, N.; Maris, J.R.; Wang, H.; Ren, J. Mitochondrial aldehyde dehydrogenase (ALDH2) protects against streptozotocin-induced diabetic cardiomyopathy: Role of GSK3beta and mitochondrial function. BMC Med. 2012, 10, 40. [CrossRef] [PubMed]

38. Penpargkul, S.; Fein, F.; Sonnenblick, E.H.; Scheuer, J. Depressed cardiac sarcoplasmic reticular function from diabetic rats. J. Mol. Cell Cardiol. 1981, 13, 303-309. [CrossRef]

39. Pierce, G.N.; Russell, J.C. Regulation of intracellular Ca2+ in the heart during diabetes. Cardiovasc. Res. 1997, 34, 41-47. [CrossRef]

40. Hayashi, T.; Mori, T.; Yamashita, C.; Miyamura, M. Regulation of Oxidative Stress and Cardioprotection in Diabetes Mellitus. Curr. Cardiol. Rev. 2008, 4, 251-258. [CrossRef] [PubMed]

41. Ding, M.; Feng, N.; Tang, D.; Feng, J.; Li, Z.; Jia, M.; Liu, Z.; Gu, X.; Wang, Y.; Fu, F.; et al. Melatonin prevents Drp1-mediated mitochondrial fission in diabetic hearts through SIRT1-PGC1 $\alpha$ pathway. J. Pineal Res. 2018, 65, e12491. [CrossRef]

42. Archer, S.L. Mitochondrial Dynamics-Mitochondrial Fission and Fusion in Human Diseases. N. Engl. J. Med. 2013, 369, 2236-2251. [CrossRef] [PubMed]

43. Chiong, M.; Cartes-Saavedra, B.; Norambuena-Soto, I.; Mondaca-Ruff, D.; Morales, P.E.; García-Miguel, M.; Mellado, R. Mitochondrial metabolism and the control of vascular smooth muscle cell proliferation. Front. Cell Dev. Biol. $2014,2,72$. [CrossRef]

44. Ong, S.B.; Hall, A.R.; Hausenloy, D.J. Mitochondrial Dynamics in Cardiovascular Health and Disease. Antioxid. Redox Signal. 2013, 19, 400-414. [CrossRef]

45. Wai, T.; García-Prieto, J.; Baker, M.J.; Merkwirth, C.; Benit, P.; Rustin, P.; Rupérez, F.J.; Barbas, C.; Ibañez, B.; Langer, T. Imbalanced OPA1 processing and mitochondrial fragmentation cause heart failure in mice. Science 2015, 350, aad0116. [CrossRef] [PubMed]

46. Martinet, W.; Knaapen, M.W.; Kockx, M.M.; De Meyer, G.R. Autophagy in cardiovascular disease. Trends Mol. Med. 2007, 13, 482-491. [CrossRef]

47. Xu, X.; Kobayashi, S.; Chen, K.; Timm, D.; Volden, P.; Huang, Y.; Gulick, J.; Yue, Z.; Robbins, J.; Epstein, P.N.; et al. Diminished Autophagy Limits Cardiac Injury in Mouse Models of Type 1 Diabetes. J. Biol. Chem. 2013, 288, 18077-18092. [CrossRef] [PubMed]

48. Guo, Y.; Yu, W.; Sun, D.; Wang, J.; Li, C.; Zhang, R.; Babcock, S.A.; Li, Y.; Liu, M.; Ma, M.; et al. A novel protective mechanism for mitochondrial aldehyde dehydrogenase (ALDH2) in type i diabetes-induced cardiac dysfunction: Role of AMPK-regulated autophagy. Biochim. Biophys. Acta 2015, 1852, 319-331. [CrossRef]

49. Chen, C.H.; Ferreira, J.C.; Gross, E.R.; Mochly-Rosen, D. Targeting Aldehyde Dehydrogenase 2: New Therapeutic Opportunities. Physiol. Rev. 2014, 94, 1-34. [CrossRef]

50. Kaludercic, N.; Di Lisa, F. Mitochondrial ROS Formation in the Pathogenesis of Diabetic Cardiomyopathy. Front. Cardiovasc. Med. 2020, 7, 12. [CrossRef]

51. Brownlee, M. The Pathobiology of Diabetic Complications: A Unifying Mechanism. Diabetes 2005, 54, 1615-1625. [CrossRef]

52. Calabrese, V.; Mancuso, C.; Sapienza, M.; Puleo, E.; Calafato, S.; Cornelius, C.; Finocchiaro, M.; Mangiameli, A.; Di Mauro, M.; Stella, A.M.; et al. Oxidative stress and cellular stress response in diabetic nephropathy. Cell Stress Chaperon. 2007, 12, 299-306. [CrossRef]

53. Chen, J.; Henderson, G.I.; Freeman, G.L. Role of 4-Hydroxynonenal in Modification of Cytochrome c Oxidase in Ischemia/Reperfused Rat Heart. J. Mol. Cell. Cardiol. 2001, 33, 1919-1927. [CrossRef]

54. Jia, G.; Demarco, V.G.; Sowers, J.R. Insulin resistance and hyperinsulinaemia in diabetic cardiomyopathy. Nat. Rev. Endocrinol. 2016, 12, 144-153. [CrossRef] [PubMed]

55. Hölscher, M.E.; Bode, C.; Bugger, H. Diabetic Cardiomyopathy: Does the Type of Diabetes Matter? Int. J. Mol. Sci. 2016, 17, 2136. [CrossRef] 
56. Raev, D.C. Which Left Ventricular Function Is Impaired Earlier in the Evolution of Diabetic Cardiomyopathy?: An echocardiographic study of young type I diabetic patients. Diabetes Care 1994, 17, 633-639. [CrossRef]

57. Pan, G.; Deshpande, M.; Thandavarayan, R.A.; Palaniyandi, S.S. ALDH2 Inhibition Potentiates High Glucose Stress-Induced Injury in Cultured Cardiomyocytes. J. Diabetes Res. 2016, 2016, 1390861. [CrossRef] [PubMed]

58. Wang, H.J.; Kang, P.F.; Wu, W.J.; Tang, Y.; Pan, Q.Q.; Ye, H.W.; Tang, B.; Li, Z.H.; Gao, Q. Changes in cardiac mitochondrial aldehyde dehydrogenase 2 activity in relation to oxidative stress and inflammatory injury in diabetic rats. Mol. Med. Rep. 2013, 8 , 686-690. [CrossRef] [PubMed]

59. Stewart, M.J.; Malek, K.; Crabb, D.W. Distribution of messenger RNAs for aldehyde dehydrogenase 1, aldehyde dehydrogenase 2, and aldehyde dehydrogenase 5 in human tissues. J. Investig. Med. 1996, 44, 42-46. [PubMed]

60. Esterbauer, H.; Schaur, R.J.; Zollner, H. Chemistry and biochemistry of 4-hydroxynonenal, malonaldehyde and related aldehydes. Free Radic. Biol. Med. 1991, 11, 81-128. [CrossRef]

61. Westermeier, F.; Riquelme, J.A.; Pavez, M.; Garrido, V.; Díaz, A.; Verdejo, H.E.; Castro, P.F.; García, L.; Lavandero, S. New Molecular Insights of Insulin in Diabetic Cardiomyopathy. Front. Physiol. 2016, 7, 125. [CrossRef]

62. Ding, Y.; Wang, Y.; Zhang, W.; Jia, Q.; Wang, X.; Li, Y.; Lv, S.; Zhang, J. Roles of Biomarkers in Myocardial Fibrosis. Aging Dis. 2020, 11, 1157-1174. [CrossRef] [PubMed]

63. Zhao, S.; Wu, H.; Xia, W.; Chen, X.; Zhu, S.; Zhang, S.; Shao, Y.; Ma, W.; Yang, D.; Zhang, J. Periostin expression is upregulated and associated with myocardial fibrosis in human failing hearts. J. Cardiol. 2014, 63, 373-378. [CrossRef] [PubMed]

64. Lin, Y.; Tang, Y.; Wang, F. The Protective Effect of HIF-1 $\alpha$ in T Lymphocytes on Cardiac Damage in Diabetic Mice. Ann. Clin. Lab. Sci. 2016, 46, 32-43. [PubMed]

65. Lennon, G.P.; Bettini, M.; Burton, A.R.; Vincent, E.; Arnold, P.Y.; Santamaria, P.; Vignali, D.A. T Cell Islet Accumulation in Type 1 Diabetes Is a Tightly Regulated, Cell-Autonomous Event. Immunity 2009, 31, 643-653. [CrossRef] [PubMed]

66. Lorenzo, O.; Picatoste, B.; Ares-Carrasco, S.; Ramírez, E.; Egido, J.; Tuñón, J. Potential role of nuclear factor kB in diabetic cardiomyopathy. Mediat. Inflamm. 2011, 2011, 652097. [CrossRef]

67. Ramezani, N.; Vanaky, B.; Shakeri, N.; Soltanian, Z.; Rad, F.F.; Shams, Z. Evaluation of Bcl-2 and Bax Expression in the Heart of Diabetic Rats after Four Weeks of High Intensity Interval Training. Med Lab. J. 2019, 13, 15-20. [CrossRef]

68. Golstein, P. Controlling Cell Death. Science 1997, 275, 1081-1082. [CrossRef]

69. Bhuvaneshwari, P.; Riswana, N.A. Apoptotic cell death in heart failure associated with diabetes. Int. J. Clin. Correl. $2019,3,12$. [CrossRef]

70. Wang, Y.; Sun, H.; Zhang, J.; Xia, Z.; Chen, W. Streptozotocin-induced diabetic cardiomyopathy in rats: Ameliorative effect of PIPERINE via Bcl2, Bax/Bcl2, and caspase-3 pathways. Biosci. Biotechnol. Biochem. 2020, 84, 2533-2544. [CrossRef]

71. Li, B.; Zheng, Z.; Wei, Y.; Wang, M.; Peng, J.; Kang, T.; Huang, X.; Xiao, J.; Li, Y.; Li, Z. Therapeutic effects of neuregulin-1 in diabetic cardiomyopathy rats. Cardiovasc. Diabetol. 2011, 10, 69. [CrossRef] [PubMed]

72. Hwang, H.V.; Sandeep, N.; Paige, S.L.; Ranjbarvaziri, S.; Hu, D.-Q.; Zhao, M.; Lan, I.S.; Coronado, M.; Kooiker, K.B.; Wu, S.M.; et al. 4HNE Impairs Myocardial Bioenergetics in Congenital Heart Disease-Induced Right Ventricular Failure. Circulation 2020, 142, 1667-1683. [CrossRef] [PubMed]

73. Hill, B.G.; Dranka, B.P.; Zou, L.; Chatham, J.C.; Darley-Usmar, V.M. Importance of the bioenergetic reserve capacity in response to cardiomyocyte stress induced by 4-hydroxynonenal. Biochem. J. 2009, 424, 99-107. [CrossRef]

74. Mak, S.; Lehotay, S.C.; Yazdanpanah, M.; Azevedo, E.R.; Liu, P.P.; Newton, G.E. Unsaturated aldehydes including 4-OH-nonenal are elevated in patients with congestive heart failure. J. Card. Fail. 2000, 6, 108-114. [CrossRef]

75. Lashina, O.M.; Szweda, P.A.; Szweda, L.I.; Romania, A.M.P. Decreased complex II respiration and HNE-modified SDH subunit in diabetic heart. Free Radic. Biol. Med. 2006, 40, 886-896. [CrossRef] [PubMed]

76. Zhong, Y.; Ahmed, S.; Grupp, I.L.; Matlib, M.A. Altered SR protein expression associated with contractile dysfunction in diabetic rat hearts. Am. J. Physiol. Heart Circ. Physiol. 2001, 281, H1137-H1147. [CrossRef] [PubMed]

77. Kanamori, H.; Takemura, G.; Goto, K.; Tsujimoto, A.; Mikami, A.; Ogino, A.; Watanabe, T.; Morishita, K.; Okada, H.; Kawasaki, M.; et al. Autophagic adaptations in diabetic cardiomyopathy differ between type 1 and type 2 diabetes. Autophagy 2015, 11, 1146-1160. [CrossRef]

78. Xie, Z.; He, C.; Zou, M.-H. AMP-activated protein kinase modulates cardiac autophagy in diabetic cardiomyopathy. Autophagy 2011, 7, 1254-1255. [CrossRef]

79. Shimomura, H.; Terasaki, F.; Hayashi, T.; Kitaura, Y.; Isomura, T.; Suma, H. Autophagic Degeneration as a Possible Mechanism of Myocardial Cell Death in Dilated Cardiomyopathy. Jpn. Circ. J. 2001, 65, 965-968. [CrossRef]

80. Xie, Z.; Lau, K.; Eby, B.; Lozano, P.; He, C.; Pennington, B.; Li, H.; Rathi, S.; Dong, Y.; Tian, R.; et al. Improvement of Cardiac Functions by Chronic Metformin Treatment Is Associated With Enhanced Cardiac Autophagy in Diabetic OVE26 Mice. Diabetes 2011, 60, 1770-1778. [CrossRef]

81. Chapple, S.J.; Cheng, X.; Mann, G.E. Effects of 4-hydroxynonenal on vascular endothelial and smooth muscle cell redox signaling and function in health and disease. Redox Biol. 2013, 1, 319-331. [CrossRef]

82. Leonarduzzi, G.; Chiarpotto, E.; Biasi, F.; Poli, G. 4-Hydroxynonenal and cholesterol oxidation products in atherosclerosis. Mol. Nutr. Food Res. 2005, 49, 1044-1049. [CrossRef] [PubMed] 
83. Vladykovskaya, E.; Sithu, S.D.; Haberzettl, P.; Wickramasinghe, N.S.; Merchant, M.L.; Hill, B.G.; McCracken, J.; Agarwal, A.; Dougherty, S.; Gordon, S.A.; et al. Lipidperoxidationproduct4-hydroxy-trans-2-nonenalcauses endothelial activation by inducing endoplasmic reticulum stress. J. Biol. Chem. 2021, 287, 11398-11409. [CrossRef] [PubMed]

84. Zeng, L.; Zampetaki, A.; Margariti, A.; Pepe, A.E.; Alam, S.; Martin, D.; Xiao, Q.; Wang, W.; Jin, Z.-G.; Cockerill, G.; et al. Sustained activation of XBP1 splicing leads to endothelial apoptosis and atherosclerosis development in response to disturbed flow. Proc. Natl. Acad. Sci. USA 2009, 106, 8326-8331. [CrossRef] [PubMed] 